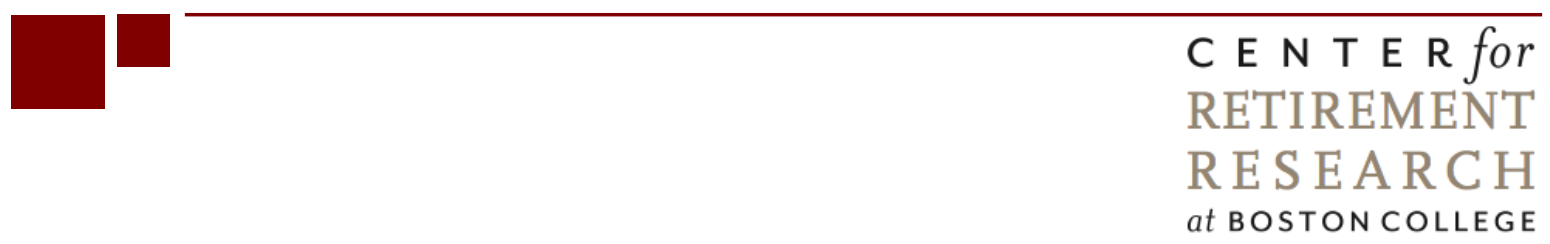

\title{
EFFECTS OF EMPLOYER HEALTH COSTS ON THE TREND AND DISTRIBUTION OF SOCIAL SECURITY-TAXABLE WAGES
}

Gary Burtless and Sveta Milusheva

CRR WP 2012-11

Date Released: April 2012

Date Submitted: February 2012

\author{
Center for Retirement Research at Boston College \\ Hovey House \\ 140 Commonwealth Avenue \\ Chestnut Hill, MA 02467
}

Tel: 617-552-1762 Fax: 617-552-0191

http://crr.bc.edu

Gary Burtless holds the John C. and Nancy D. Whitehead Chair in Economic Studies at the Brookings Institution. Sveta Milusheva is a senior research assistant at the Brookings Institution. The research reported herein was pursuant to a grant from the U.S. Social Security Administration (SSA), funded as part of the Retirement Research Consortium (RRC). The opinions and conclusions expressed are solely those of the authors and do not represent the views of SSA, any agency of the federal government, the RRC, the Brookings Institution, or Boston College. The authors are grateful to Kathleen Burke for excellent research help.

(C) 2012, Gary Burtless and Sveta Milusheva. All rights reserved. Short sections of text, not to exceed two paragraphs, may be quoted without explicit permission provided that full credit, including (C) notice, is given to the source. 


\title{
About the Center for Retirement Research
}

The Center for Retirement Research at Boston College, part of a consortium that includes parallel centers at the University of Michigan and the National Bureau of Economic Research, was established in 1998 through a grant from the Social Security Administration. The Center's mission is to produce first-class research and forge a strong link between the academic community and decision-makers in the public and private sectors around an issue of critical importance to the nation's future. To achieve this mission, the Center sponsors a wide variety of research projects, transmits new findings to a broad audience, trains new scholars, and broadens access to valuable data sources.

\author{
Center for Retirement Research at Boston College \\ Hovey House \\ 140 Commonwealth Avenue \\ Chestnut Hill, MA 02467 \\ phone: 617-552-1762 fax: 617-552-0191 \\ e-mail: crr@bc.edu \\ crr.bc.edu
}

Affiliated Institutions:

The Brookings Institution

Massachusetts Institute of Technology

Syracuse University

Urban Institute 


\begin{abstract}
The increasing cost of employer contributions for employee health insurance reduces the percentage of compensation that is subject to the payroll tax. Rising insurance contributions can also have a more subtle effect on the Social Security tax base because they influence the distribution of money wages. Workers bear most of the burden of employer health contributions through lower money wages. Any change in the average cost and distribution of costs of employer health plans can have an effect on the distribution of wages and the percentage of wages subject to the payroll tax. This paper uses the Medical Expenditure Panel Survey (MEPS) to analyze trends in the cost of employer health contributions and the cross-worker distribution of health contributions. Our analysis shows that the 1996-2008 increase in employer health premiums was faster than overall compensation increases but only slightly faster among workers below the taxable maximum compared with those above the maximum. However, because employer health insurance premiums represent a much higher percentage of compensation below the maximum taxed earnings amount, the effect of health cost trends exerted a disproportionate downward pressure on money wages below the taxable maximum, reducing the percentage of compensation subject to the payroll tax. We simulated the implications of the health reform law on the trend in employer health costs around 2016. We find only slight effects on the fraction of worker compensation that will be subject to Social Security taxes. The higher insurance costs faced by employers who will be required to offer health plans will be approximately offset by lower health costs on the part of employers who will see some insured employees accept subsidized health insurance outside of an employer plan. The main long-term impact of reform on the taxable wage base is likely to be through its effect on the trend in underlying health care costs.
\end{abstract}




\section{Introduction}

The increasing cost of employer contributions for employee health insurance reduces the percentage of labor compensation that is subject to the payroll tax. Rising health insurance contributions also have a more subtle effect on Social Security because they influence the distribution of money wages and the percentage of wages below the taxable cap. Workers bear most of the burden of employer health contributions through lower money wages, which implies that the distribution of money wages is directly affected by the distribution of employer health contributions across workers. Any change in the average cost and distribution of the costs of employer health plans can have an effect on the distribution of wages and the percentage of wages subject to the payroll tax.

The revenue base for the Social Security program consists of money wages and net selfemployment income, in particular, earned incomes below an annual maximum amount. Compensation other than money wages, including employer contributions for social insurance, private pensions, and employee health and other insurance benefits, is excluded from the tax base. Relative to compensation, employer contributions for both private pensions and social insurance contributions have declined since reaching peaks in 1980 and 1994, respectively. Contributions for health insurance, however, have continued to rise, climbing from $3.7 \%$ of compensation in 1980 to more than $7.0 \%$ of compensation in 2010. As a result the ratio of money earnings to labor compensation reached an all time low in 2009 and 2010.

The fraction of money earnings subject to Social Security taxes is also affected by the distribution of wages. Growing inequality increases the percentage of money wages above the taxable maximum and reduces the effective tax rate on wages. Growing inequality reduced the share of earnings below the taxable maximum from about $92 \%$ of earnings in 1983 to 83\% in 2006 (Technical Panel on Assumptions and Methods 2007). If employer contributions for health insurance were fully reflected as lower money wages, the rising cost of health insurance could in principle contribute to rising inequality. Most employer health plans cost as much for highly paid employees as they do for insured employees earning a much lower wage so long as the expected health reimbursement costs for high and low paid employees are approximately the same. When employer health contributions per employee increase faster than average money wages, as has been the case for the past four decades, the effect in proportional terms can be greater for low-wage than for high-wage workers. The cost of the health plan represents a much 
larger component of the compensation paid to insured low-wage as opposed to high-wage workers.

Of course, many workers are not covered by an employer-sponsored health plan, and lack of coverage is particularly common among low-wage workers. Nonetheless, the rising cost of health insurance has an undeniable effect on the share of compensation subject to Social Security taxes and, because of the possible effect on earnings inequality, it may also adversely affect the fraction of money wages below the taxable maximum amount. By changing employers' and workers' incentives to maintain or participate in employer-sponsored health plans, health insurance reform under the Affordable Care Act (P.L. 111-148) may cause a shift in either the cost of employer-sponsored plans or in the distribution of these costs across the workforce. Either of these shifts can affect the percentage of compensation taxed by the Social Security system. This paper estimates the effect of rising health contributions on wage inequality and on the money wage / compensation ratio, and assesses how these trends will be affected by changes in health insurance costs and coverage following health reform.

We find that the rise in employer health costs in combination with rising wage inequality significantly reduced the percentage of compensation taxed by Social Security during the period we analyzed. In a stylized model that tracks observed trends in employer health insurance contributions per worker and wage growth above and below the taxable earnings ceiling, we find that between 1996 and 2008 the proportion of compensation that consists of money wages fell $1.2 \%$. In the same time span, the proportion of compensation that consists of money wages taxable by Social Security fell 3.1\%. These declines were caused by the complicated interaction between rising health care costs, which in absolute terms are similar for workers above and below the taxable wage ceiling, and growing inequality in wages and compensation, which causes the rise in health costs to have a much bigger proportional impact on wages below the taxable earnings ceiling. Our simulation analysis suggests that between 1996 and 2008 rising employer health costs for workers below the taxable wage ceiling caused the ratio of money wages to compensation to fall $1.8 \%$ among those workers. As a result, the share of total compensation paid to these workers that was taxed by Social Security also fell 1.8\%. Among workers with wages above the wage ceiling, however, the growth in employer health costs only caused the proportion of compensation paid as wages to decline $0.2 \%$. However, the combined effect of increased wage inequality and rising employer health costs caused the share of 
compensation taxed by Social Security to fall 5.7\% among these high-wage workers. Combining the estimated effects on workers above and below the taxable earnings ceiling, the overall impact was to reduce the ratio of taxed wage earnings to compensation by $3.1 \%$. The interaction between rising health costs and growing wage inequality has produced notable erosion in the Social Security taxable wage base.

Our analysis of the impact of the Affordable Care Act on taxable earnings focuses on changes in the cost of employer health contributions that will arise because many workers will see a change in the source of their health coverage. Some previously uncovered workers will receive employer coverage because their employers will be induced to offer a health plan. Some workers previously insured by their employers’ plans will switch to publicly subsidized plans because such plans may be cheaper or provide more comprehensive benefits. The first kind of change in coverage boosts employer health costs and is likely to lead to lower money wages. The second reduces employer health costs and should result in higher money wages. Although many workers will see a change in their health coverage or the source of their coverage, we find that the net effect of reform on the ratio of Social Security-taxed wages to total employee compensation is likely to be modest. Coverage changes that boost employer health costs will probably be somewhat less costly to employers than coverage changes that shift the burden of subsidizing insurance coverage from employers to the government. The main impact of health reform on the share of worker compensation that is taxed by Social Security is likely to occur through a different channel, one that we do not analyze here. If reform affects the trend in health costs, in particular, if it reduces the gap between the rate of growth in health spending per person and in wages, there will be a noticeable slowdown in the erosion of the Social Security tax base.

\section{Background}

The Social Security payroll tax is imposed on wage and salary income in jobs covered by the program and on net self-employment income. Wage and salary workers and their employers do not pay the Social Security tax on most supplements to money wages, including employer premium payments for health and other group insurance plans, employer social insurance contributions, and employer contributions to worker retirement plans. Over the past six decades all these forms of wage supplementation have become more important components of employee compensation (Figure 1). Whereas employer contributions for nonwage compensation represented $5 \%$ of total compensation in 1950, they accounted for almost $20 \%$ of compensation 
by 2010. Most forms of nonwage compensation stabilized or even declined after reaching a peak sometime between 1975 and 1995. Employer contributions for employee health plans represent an exception to this pattern. Employer payments for health insurance premiums have continued to increase, both as a proportion of total employee compensation and in relation to total wage payments. Between 1980 and 2010 the share of compensation paid out as money wages fell 3.0 percentage points. The share paid out as employer contributions to employee health plans increased 3.3 percentage points. Thus, more than all of decline in compensation paid as wages occurred because of the continued rapid growth in employer health outlays.

The increase in nonwage compensation is not the only development affecting the share of employee labor earnings taxed by Social Security. Two other factors are also important- the fraction of wage and salary employment covered by the Social Security program and the distribution of covered wages and self-employment income above and below the maximum earnings amount taxed by Social Security. In most of the post-war period expansions in Social Security coverage typically increased the share of U.S. wages that were subject to Social Security taxes, but in the past decade the percentage of wages covered by the program has edged down slightly. The percentage of covered earnings that are actually taxed has been more variable, however. In 2005 the maximum annual earnings subject to the Social Security payroll tax was $\$ 90,000$. Tabulations of the $\mathrm{W}-2$ wage reporting forms show that $94.1 \%$ of wage earners had annual earnings less than this amount while 5.9\% earned more. However, workers earning more than the taxable maximum earned $30.0 \%$ of all reported wages, and nearly half the wages they earned was above the taxable maximum amount. As wages have grown more unequal a rising percentage of covered earnings has been above the taxable maximum amount. The proportion of untaxed earnings is somewhat cyclical, because the wages of very high earners tend to be highly sensitive to the state of the economy (Figure 2).

Most labor economists believe that in the long run much or all the burden of employer costs for fringe benefits falls on workers (Blumberg 1999; Gruber 2000; Jensen and Morrisey 2001). If employers are largely indifferent about the composition of pay they offer workers, the elements of the compensation package will be determined by the legal constraints faced by employers and by workers' preferences. American employers are obliged to make social insurance contributions for Social Security and unemployment compensation, but they are not currently required to provide health insurance or firm-sponsored retirement benefits to their 
employees. Because workers are free to find employment with employers that do not provide these benefits, it is widely assumed that the nonmandatory benefits provided to employees must be worth approximately as much to the workers who receive them as the net pay they give up in order to obtain them. Employer contributions for health and retirement benefits receive a substantial income tax preference. Many workers may prefer to receive compensation in the form of untaxed health benefits or lightly taxed retirement benefits rather than fully taxed money wage payments. The tax preference is more valuable to workers who earn higher pay, which helps account for the strong positive correlation between average workplace earnings and an employer's offer of tax-preferred fringe benefits. A second consideration also makes it attractive for workers to obtain health insurance through the workplace. Insurance is substantially less costly when purchased for a group rather than when obtained in the individual market. The adverse selection problem is smaller for large pre-defined groups compared with individual workers seeking to obtain insurance on their own. Moreover, there are sizeable administrative savings in marketing and search in the group market compared with the market for individual health insurance.

Assuming that workers ultimately pay for employer-provided health benefits, how has the distribution of these benefits across workers affected the level and distribution of Social Security-taxable wages? To answer this question precisely would require a model of the determinants of the distribution of compensation and detailed evidence on the statistical relationship between wages and health benefits, both at the level of the firm and across workers at different points in the compensation distribution. We will not develop such a model in this paper. Instead we will analyze evidence on the distribution of employer health costs across individual workers and over a 13-year span ending in 2008. Employer health costs grew much faster than money wages over this period. The basic structure of employer health plans did not appear to grow more generous, but charges by health care providers increased much faster than either consumer prices or worker compensation. Under the maintained assumption that increasing employer health costs substituted for wage increases firms would otherwise have given to their workers, we can use detailed information about employer costs and employee coverage to determine the distribution of wage increases that workers would otherwise have received. These same distributional analyses can also shed light on whether the missing wage 
increases had a larger impact on wage gains below or above the maximum Social Security taxable wage.

\section{Data}

Our detailed analysis of the distribution of employer health insurance costs is based on microdata contained in the Medical Expenditure Panel Survey (MEPS) household survey files and averaged employer responses from the MEPS employer survey. The MEPS research program has three basic components, a survey of representative households, a survey of the medical providers who supply services to these households, and a national survey of public and private employers to gather information on the types and cost of employee health insurance offered. ${ }^{1}$ The MEPS household and provider surveys offer unusually comprehensive information on health care utilization, spending on health care and insurance, and sources of payment for personal health care goods and services. In addition, the household survey provides information on household cash income and its components, including wages, for a nationally representative sample of the noninstitutionalized population. For purposes of estimating the distribution of health care consumption and payments in the employed population, the combined information from the household survey and the survey of medical providers offers an unparalleled source of data. In combination the surveys give detailed information on the insurance coverage of workers and their dependents, the premium cost to workers of their insurance, their utilization of health care providers, the cost of medical goods and services that providers supply, and the cost of and the sources of payment for the care received by working respondents and their dependents. Because the reports of household respondents are crosschecked against the responses of providers, the MEPS survey files provide much more accurate information about the cost and sources of payment for medical services than would be possible in a survey aimed solely at households.

The MEPS household survey collects information from a given sample (or panel) of families in five separate interviews that cover two calendar years. The analysis reported here is based on insurance coverage, earnings, medical care, and health spending reports of the MEPS panels covering calendar years 1996 to 2008. The MEPS household survey gives us information

${ }^{1}$ For a more detailed description of the MEPS program and its component surveys, see the introductory material in Bernard and Banthin (2007). 
on wage earnings, health spending, and insurance coverage and reimbursement for a total of about 161,000 worker observation years, or approximately 12,500 worker observations per year. In addition, the survey files also contain information on the health spending, insurance coverage, and reimbursement of worker dependents. Most of our analysis focuses on the wages, health insurance coverage, and health spending of working sample members and their dependents who were present at the end of December in each calendar year. Since MEPS households are included in the sample for a period of two years, it is possible that some household members who were present before December in a particular calendar year will be absent from the household in December.

Although the MEPS household survey provides extensive information on the types of providers who supply medical care to people in the sample, our focus is on the employer and employee cost of insurance, the total cost of care received by workers and their dependents, the portion of costs that are directly paid by the person receiving care and by employer-sponsored insurance plans, and the cost of health insurance premiums. The MEPS household survey files permit us to measure the total cost of care received by individual household members and to determine the fraction of this cost that is paid by the household and by individual third-party payers, including employer-provided insurance plans.

The MEPS household survey data have important limitations for assessing the employer and employee cost and value of insurance plans covering the survey respondents. Although the MEPS employer survey obtains extensive cost data directly from employers, none of the cost data are linked to individual workers or to households in the MEPS household survey. As a result, we do not know the cost to employers of paying health insurance premiums on behalf of respondents in the MEPS household sample. As noted above, the MEPS household data file includes information on payments from employer-sponsored insurance plans to reimburse providers and households for the cost of medical care. It does not, however, contain any information about employers' costs of managing their health insurance plans or paying for third parties to manage their plans. Thus, an important component of respondents' health consumption - the consumption of health insurance administrative services by workers in employer-sponsored plans - is missing from the household survey files. In addition, the MEPS household survey has incomplete information on respondents' insurance premium payments. For calendar years 1996-2000 respondents were not asked to report their premium payments if 
they had employment-based insurance coverage. Starting in 2001, these premiums were reported to MEPS household survey interviewers.

The MEPS employer survey provides a much better source of information for employer insurance costs as well as for employees’ premium contributions between 1996 and 2000. Even though the information is not linked to the specific workers in the MEPS household survey, we can impute employer and employee premiums to workers in the MEPS household sample based on the averaged responses of employers interviewed in the MEPS employer survey. We performed this imputation by dividing employer-insured employees in the MEPS household sample into 10 groups based on the industry in which they are employed, Employees were divided among 9 standard private industrial groups and the government. Employees of private firms were further subdivided into those working in establishments with fewer than 50 employees and with 50 or more. The national average premium amounts within these categories, as determined in the MEPS employer survey, were then imputed to MEPS household respondents. $^{2}$ Between 1996 and 2000 the MEPS employer survey provided premium estimates for individual employee coverage and for coverage under a family plan. Starting in 2001 the employer survey provided additional detail on family premiums. Between 2001 and 2008 we could impute the premium payments for individual plans, for plans covering the employee plus one dependent, and for plans covering the employee plus two or more dependents. No MEPS employer survey was conducted in 2007, so we imputed employer and employee premiums based on an average of the values within a category estimated in the 2006 and 2008 surveys. In all remaining years our premium imputations are based on estimates derived from the MEPS employer survey for the same calendar year.

\section{Distribution of employer health contributions and employee wages}

Figure 3 shows trends in the total premium cost of family coverage and individual employee coverage in private-sector employer-sponsored insurance plans as estimated with the MEPS employer survey data (Crimmel 2009a and 2009b). Between 1996 and 2008 the estimated cost of an average family plan increased at an annual compound rate of $7.7 \%$, while

${ }^{2}$ In cases where MEPS household respondents did not report the establishment size of their employers we imputed the average premium in their industry, regardless of household size. Where respondents failed to report the insured employee's industry, we imputed the U.S. employer average premium payment. 
the cost of individual plans increased 6.8\% a year. For purposes of comparison, average U.S. annual earnings increased 3.5\% a year and consumer prices increased $2.4 \%$ a year during the same period. ${ }^{3}$ Total premium costs are split between employers and employees. The MEPS employer survey shows little change in the percentage of the total premium cost of a family plan that is borne by employers. Between 1996 and 2009 employers on average paid close to threequarters of the total cost of health insurance premiums for a family plan. The MEPS employer survey shows a modest decline in the percentage of premiums paid by employers for individual plans. In 1996-1997 employers covered 84\% of the total cost of an individual plan premium; in 2008-2009 they paid 80\% of the cost.

The employer cost of providing health insurance to employees depends not only on health premiums but also on the proportion of workers who take up the insurance offer and on workers' decisions to enroll in an individual or a family plan. A key relationship for determining the impact of health insurance costs on the distribution of compensation is the link between workers' wage levels and the offer and take-up of an employer health plan. Figure 4 shows evidence on this link based on tabulations of the MEPS household survey. The top panel shows the percentage of wage and salary workers in each tenth of the annual wage distribution who are offered the option of enrolling in a health plan provided by their employer. Note that some workers who are not offered health insurance at their place of employment may nonetheless obtain employer-sponsored insurance as a dependent under a spouse's or other family member's plan. We classify these workers as "not offered" an employer-sponsored plan at their place of work.

The data points in the top panel of Figure 4 show the relationship between workers' positions in the wage distribution and the probability they will be offered health insurance by their employers. The data cover enrollment offer rates at the start of the analysis period, in 19961997, and at the end, in 2007-2008. Perhaps surprisingly, the overall offer rate increased slightly over the period. In 1996-1997, 69\% of wage and salary workers in the MEPS household survey were offered enrollment in a health plan. By 2007-2008 the share edged up to 70\%. The increased offer rate was concentrated in the $2^{\text {nd }}$ and $3^{\text {rd }}$ deciles of the wage distribution. Offer

${ }^{3}$ Average annual wages are reported every year by the Social Security Administration based on data from a large sample of W-2 forms. We calculated the change in consumer prices using BLS's CPI-U-RS series. 
rates declined slightly in the top half of the wage distribution. In both sets of years there is a strong positive correlation between workers' wages and their chance of being offered health insurance by their employers. In the bottom fifth of the wage distribution far less than half of workers are offered a health plan, while in the top fifth about $90 \%$ are offered insurance.

Percentages of workers offered enrollment who actually enroll in their employers' health plans are shown in the middle columns of Table 1. Our tabulations show a decline in insurance take-up rates over the analysis period, with the biggest declines occurring at the bottom of the wage distribution. In the bottom tenth of the wage distribution, only $37 \%$ of workers who were offered enrollment in an employer-sponsored plan accepted the offer in 2007-2008. In the earlier period, $58 \%$ of workers at the bottom of the wage distribution took up the offer. Take-up rates fell in the bottom half of the wage distribution while increasing slightly in the top half of the distribution. The offsetting effects of higher offer rates and lower take-up rates produced small net effects on insurance enrollment rates over the analysis period (see the lower panel in Figure 4 and the right-hand columns in Table 1). The most noticeable changes occurred in the bottom deciles of the wage distribution. Participation in employer-sponsored plans fell in the bottom tenth but increased in the next higher tenth of the distribution.

The cost to an employer if a worker enrolls in a family plan is more than twice the cost of the worker's enrollment in an individual plan. Furthermore, the cost ratio has been rising over time (Figure 3). Thus, the insurance cost burden on employers depends crucially on the proportion of participating workers who enroll in family and individual plans. The MEPS household survey shows that enrollment in more costly family plans has declined over time, and this pattern is evident for both high- and low-wage workers (Figure 5). This trend has offset a small part of the rapid growth in health insurance premiums.

The implications of Figures 3 through 5 for average employer health costs are displayed in Figure 6. Each data point in Figure 6 shows the average employer cost of health insurance provided to workers in a given wage decile. For example, the average employer cost of wage insurance in the $6^{\text {th }}$ wage decile was $\$ 1,844$ in 1996-1997 and \$3,911 in 2007-2008. Employees in the $6^{\text {th }}$ decile who were not offered employer-sponsored insurance or who declined to enroll in their employer's plan imposed no health costs on their employers. Slightly less than threequarters of the wage and salary workers in the $6^{\text {th }}$ decile participated in an employer plan, and the 
participating workers on average cost their employers $\$ 2,500$ in $1996-1997$ and $\$ 5,400$ in 2007 2008.

Another way to assess the benefit that workers derive from their employer health plan is to sum the health care reimbursements they and their dependents receive under the plan and then subtract the employee premium they pay in order to obtain coverage. The MEPS household survey data contains data on insurance reimbursement received by workers and their insured dependents and on the premiums they pay for employer-sponsored health insurance. Because the employee premium reports only began in 2001, we imputed estimates of employee premiums using the industry and plan averages estimated in the MEPS employer survey for all years 19962008. (The imputation procedure is the same one we used to impute employer payments for employee health coverage.) The net benefit that an individual worker derives from employer health insurance plans, $B_{i}$, is

$$
B_{i}=\sum R_{i j}-P_{i}
$$

where $\quad B_{i}=$ Net gain obtained by worker $i$;

$R_{i j}=$ Insurance reimbursement received for the medical expenses of the worker's $j^{\text {th }}$ dependent; and

$P_{i}=$ Worker's premium payment for health insurance.

The excess of the worker's total insurance reimbursements over the out-of-pocket payments made for insurance premiums is a crude and erratic indicator of the value of the insurance plan to a particular worker. Many workers who are covered by employer health plan receive little or no reimbursed health care over the course of a year, either for themselves or for dependents covered by the plan. These workers pay more for insurance in that year than the amount of care that is reimbursed by their plan. On the other hand, a few workers receive reimbursement payments far in excess of their premium payments, because they or their covered dependents incur major medical expenses over the course of a year. ${ }^{4}$ While $B_{i}$, provides a poor indicator of the value of insurance to a particular insured worker, when these net benefits are averaged over a large number of workers the average value offers a reasonable indicator of the "excess reimbursement” workers typically receive, that is, the average insurance reimbursement in excess of the workers' average premium payments.

\footnotetext{
${ }^{4}$ Burtless and Svaton (2010) present tabulations of the highly skew distribution of reimbursed medical expenses minus health insurance premiums.
} 
Table 2 shows our estimates of excess reimbursement as a percent of the estimated insurance premium payments of employers who sponsor group health plans. Not surprisingly, the excess reimbursements received by workers are smaller than the premium payments made by employers. There are a couple of reasons for the discrepancy. The premium payments of workers and employers must cover the administrative costs of employer-sponsored health insurance and possibly a margin for profit if the insurance is provided through a private insurer. Because we are only considering reimbursement payments to health providers in our estimates of excess reimbursement, administrative expenses will be reflected in the denominator but not the numerator of the ratios reported in Table 2. In addition, the MEPS household survey misses some of the health care spending and insurance reimbursement received by workers and their dependents (see Sing et al. 2006).

Over all 13 years covered by our analysis we estimate that excess insurance reimbursement represented about $45 \%$ of the cost of employer premiums (see right-hand column in Table 2). This estimate almost certainly understates the true ratio. We suspect the MEPS employer survey estimates of employer contributions to health plans are more complete and reliable than the MEPS household survey estimates of health care spending and insurance reimbursement. There appears to have been a decline in the ratio of excess reimbursement to employer premiums during the late 1990s, but the ratio seems to have stabilized after 2000. Workers at the bottom and the top of the wage distribution typically received more insurance reimbursement per dollar of employer contribution than workers in the middle of the wage distribution. This may either indicate that workers in the low- and high-wage groups were enrolled in unusually rich plans, which received exceptionally generous employer contributions, or were more likely to incur large medical expenses. The basic lesson of Table 2 is that workers in all parts of the income distribution received larger reimbursements from their employerprovided insurance than they paid in employee premiums, and the excess reimbursements they received rose almost as rapidly as employer insurance premiums.

With wage reports from a large sample of workers and plausible estimates of employer health contributions for the same sample of workers it is straightforward to estimate the relationship between employer premiums and wages as well as the trend in this relationship over time. Figure 7 shows this relationship in two pairs of years at the beginning and at the end of our analysis period. On average employer health premiums represented $6.1 \%$ of annual wages in 
1996-1997 and increased to 8.5\% of annual wages in 2007-2008. In both years employer premiums varied widely across the wage distribution. Not surprisingly, premiums are a small fraction of wages at the top of the wage distribution. They tend to be highest as a fraction of wages between the $25^{\text {th }}$ and $40^{\text {th }}$ percentiles of the wage distribution.

Figure 8 shows the change in average employer health premiums between 1996 and 2008 in different parts of the wage distribution. The top panel shows the annual rate of change in employer outlays on health contributions, and the bottom panel shows the percentage-point change in health premiums measured as a fraction of employee wages. The slowest rate of growth in employer premium payments occurred in the bottom one-tenth of the wage distribution; the fastest was in the second one-tenth of the distribution. As we have seen, the main factors behind the differential rates of growth were changes in employee participation rates across the wage distribution and changing patterns of enrollment in individual versus more costly family plans. On the whole, however, wage earners in the top $80 \%$ of the wage distribution saw similar rates of growth in employer contributions to their health plans. Only at the bottom of the distribution were there noticeable differences in rate of increase in employer premiums.

Even if the employer wage premiums increased at a similar rate across most of the wage distribution, the gains represented very unequal proportions of workers' annual wages. The bottom panel of Figure 8 shows that between 1996 and 2008 employer premiums climbed 3 or more percentage points as a percentage of wages in the $2^{\text {nd }}$ through the $6^{\text {th }}$ wage decile. As a proportion of wages they increased more slowly in the upper part of the distribution, rising just 1.1 percentage point of wages in the top earnings decile. At the very bottom of the wage distribution, employer health insurance premiums actually declined as a percentage of wages. The drop resulted primarily from a drop in low-wage employee participation in employer health plans, especially in the most costly types of plans. If productivity and worker marginal products increased at a uniform rate in all wage deciles, the rising cost of health insurance would have depressed that rate of money wage growth by the greatest proportional amount in the $2^{\text {nd }}$ through the $6^{\text {th }}$ wage deciles. The smallest proportional effects were at the top and bottom of the wage distribution.

Figure 9 shows detailed estimates of the annual rate of growth in real wages, real employer health premiums, and the sum of wages plus health premiums across the earnings distribution. We calculated annual rates of change between 1996-1997 and 2007-2008 after 
adjusting both wages and employer insurance premiums using the CPI-U-RS consumer price deflator. Our tabulations of wage gains show the familiar U-shaped pattern other analysts have uncovered when analyzing earnings gains since the early 1990s (see Autor 2010, p. 3). Money earnings have grown faster at the top and bottom of the wage distribution compared with the middle. The growth in employer health costs for high-, middle-, and low-wage workers provides a small part of the explanation for this pattern. At the very bottom of the wage distribution, workers are less likely to receive health insurance benefits, reducing the cost to employers of providing these benefits. This leaves more room for changes in real compensation to take the form of increases in money wages. At the top of the distribution, employer costs for providing employee health benefits are increasing as fast as they are for workers in the middle of the distribution. However, the employer cost of providing health benefits to highly compensated workers is only a very small part of worker compensation. Consequently, the rapid growth in employer health costs has only a small impact on employers' ability to give these workers large increases in money wages.

\section{Implications for the Social Security tax base}

The estimated growth in employer health insurance premiums observed in the MEPS surveys follows a pattern that is similar to the aggregate pattern visible in the national income and product accounts (Figure 10). Both series show employer premiums were stable or declining in relation to money wages in the mid-1990s, rose steadily from the late 1990s through 2005, and then declined or stabilized relative to wages after 2005. The estimated growth in the ratio of employer premiums to wages is somewhat faster in the MEPS surveys than in the NIPA accounts, but over the period from 2001 through 2008 the two series show a very similar pattern of change over time.

One reason for the close correspondence is the striking similarity between average wages as reported in the MEPS household survey and average wages reported to the tax authorities and reflected in the national income and product accounts. Over the 13 years in our analysis period, the ratio of the average annual MEPS wage to the average U.S. wage as estimated with W-2 forms was $100.0 \%$ with a standard deviation of 1.9 percentage points. The similarity of the average wage amounts is somewhat misleading. Like other public use files released by government agencies, the MEPS household income data are top-coded. Thus, the wages of earners with very high wage amounts are not accurately reported in the file. If the wages of top 
earners are underreported while the average wage amount is close to the national average wage, it follows that many earners with low or moderate wage amounts must be overestimating their wage earnings. Indeed, when the earnings distribution in the MEPS household survey is compared with the wage distribution implied by the W-2 forms for identical calendar years it appears there are too few wage earners with low annual wage amounts. (This is also a problem in the March Current Population Survey, which is the source of the Census Bureau's estimates of annual wages.) The correspondence between the MEPS wage reports and the wage distribution in the $\mathrm{W}-2$ records is reasonably close in the middle of the distribution up through the $90^{\text {th }}$ wage percentile, but MEPS-reported wages above the $90^{\text {th }}$ percentile fall increasingly far below reported wages in the $\mathrm{W}-2$ records.

Figure 11 shows estimates of the ratio of employer health premiums to employee wages for workers who are above and below the maximum wage taxed by Social Security. We show two estimates of these ratios. The first, reflected with the solid lines in the chart, shows our basic estimates from the MEPS household survey file, with imputed earnings premium amounts based on averaged responses in the MEPS employer survey. The second, displayed as broken lines in the chart, shows our estimates of the average premium / average wage ratios when we adjust the MEPS household survey wage data to reflect accurately the trends in average earnings above and below the maximum taxable earnings amount. Our adjustment is straightforward. We assume that MEPS household respondents have given wage reports that permit us to accurately determine their rank in the annual earnings distribution, even though reported earnings amounts tend to overstate earnings in lower ranks of the wage distribution and understate earnings at the top of the distribution. We then use workers earnings ranks (rather than their exact reported earnings) to determine which respondents are above and which are below the maximum taxable earnings amounts. This procedure permits us to use national wage data published by the Social Security Administration to determine average wage amounts above and below the maximum taxable earnings amount, but to use MEPS estimates of employer premium contributions to determine the average health premiums of workers above and below the maximum taxable earnings amount.

Although these adjustments do not have much effect on the overall average ratio of employer premium contributions to wages, they have a sizeable effect on the estimated relative size of premiums of workers who are above and below the maximum taxable wage level. 
Because on average low-pay workers tend to overstate their wages, the adjustment increases our estimate of the average premium / average wage ratio among the workers below the maximum taxed earnings amount. In the MEPS sample the estimated ratio between 1996 and 2008 was 8.2\%. After we make the earnings adjustment, the ratio increases to 9.3\%. The adjustment has the opposite effect on the average premium / average wage ratio among high-wage workers. For workers with earnings above the taxable maximum, the average ratio between 1996 and 2008 falls from $3.3 \%$ in the MEPS data to $2.4 \%$ after we make the adjustment for understated earnings among top earners.

Figure 12 shows one other adjustment to the MEPS tabulations, an adjustment for the apparent understatement of average employer premiums in the first few years of our analysis period. As displayed in Figure 10, our imputations of employer premiums appear somewhat lower than comparable estimates in the national income and product accounts between 1996 and 2000. This may be either because the MEPS data lead us to underestimate the proportion of workers who are enrolled in costly employer health plans or because the imputed premium amounts are lower than those reflected in the national income and product accounts. Whatever the reason for the discrepancy, Figure 12 gives a straightforward estimate of how trends in the average premium / average wage ratio would be affected if we adjusted MEPS premium imputations so they duplicated the premium / wage ratio trend reflected in the national income and product accounts. The adjustments are very small in 2001 and later years and somewhat larger in the first five years of the analysis period.

Our results can be used to assess the potential impact of increased employer health costs on the share of compensation subject to the Social Security payroll tax. To perform this assessment we assume that the trend in employer compensation and its distribution across workers is unaffected by the increase in health insurance costs. We assume the only impact of changing health costs has been on the components of taxed and untaxed compensation received by workers in different parts of the wage distribution. If there were no upper limit on wages subject to the Social Security payroll tax, as is the case with the Medicare tax, the analysis would be trivial. Excess growth in untaxed health benefits would simply slow the growth of other taxed and untaxed components of compensation. The only interesting question is the total amount of slowdown in money wage payments as opposed to other non-health components of compensation. The existence of a limit on taxed earnings makes it more complicated to assess 
the impact of higher insurance premiums on Social Security taxable earnings. The impact clearly depends on the relative increase in premiums among workers above and below the maximum taxed earnings amount and on the pattern of overall compensation increases in different parts of the distribution. Our analysis focuses on employer health premium costs. We calculate employer costs for Social Security and Medicare contributions. Since we have not analyzed the distribution of other untaxed fringe benefits, such as employer pensions, we cannot perform a detailed analysis of their impact and will assume that they will continue to rise proportionally with money wages.

To simplify the analysis we assume there are two groups of workers, one that always has earnings below the taxable maximum earnings amount and another that always has earnings above that amount. This is only a small oversimplification, since the proportion of wage earners above the taxable maximum has remained quite stable for a decade and a half. Over the historical period we analyzed, employer health insurance premiums increased 5.77\% a year, while annual money wages increased 3.93\% a year among earners with wages below that taxable maximum and $4.50 \%$ a year among earners with wages above the maximum. ${ }^{5}$ Clearly, the differential rate of increase in wages above and below the taxable maximum reduced the percentage of wages subject to the payroll tax, since a disproportionate percentage of wage increases were received by earners who did not pay taxes on their marginal wage gains. Regardless where in the wage distribution earnings gains occur, however, they will be reflected in the average amount of wages earned in the economy. Since the taxable maximum earnings amount is indexed to the growth in the average wage, an increase in average wages increases the cap on wages that are subject to the Social Security payroll tax. To perform our simulation we compare the effects of two basic assumptions about the trend in employer health premium costs. First, we assume that employer health costs per worker increase 5.77\% a year, the actual historical average between 1996 and 2008. The other components of wage and nonwage compensation grow proportionately more slowly in order to accommodate a growth in health care costs that substantially exceeds the growth in overall compensation. Under our alternative scenario we assume that employer health care contributions grow exactly as fast as overall

\footnotetext{
${ }^{5}$ Our analysis of the MEPS files suggests that health premium costs increased slightly faster among workers below the taxable maximum earnings amount than among workers above the taxable maximum $5.8 \%$ versus $5.5 \%$. Over a 13-year period, however, this small difference does not have a material effect on the simulation results, so we will disregard it here.
} 
compensation. This may be accomplished as a result of slower growth in provider charges, faster growth in required premium contributions from employees, or faster growth in required cost sharing by employees. In any event, average employer health contributions per employee are assumed to increase precisely as fast as overall compensation for workers below the taxable maximum earnings amount and above that maximum amount.

Table 3 shows the implications of these assumptions for the percentage share of selected components of employee compensation in the overall pay package. To make the findings more understandable we separately report our predictions for workers with earnings below the taxable maximum amount (the top panel in Table 3), above the taxable maximum (middle panel), and both groups of earners combined (the bottom panel). We show simulation results for three years, 1996, 2008, and 2020. The first two years are the start and end dates of our historical data. In each panel we present three sets of estimates. The first shows the trend in compensation elements, measured as a percent of total employee compensation, under the assumption that employer health costs grow 5.77\% a year, considerably faster than average employee compensation. The second shows the trend in compensation components under the assumption that employer premium costs grow exactly as fast as total employee compensation. The last set of numbers shows the percentage-point change in each compensation component under the alternative scenario compared with our baseline scenario.

In the top panel, for example, the employer health cost share of compensation increases from $6.97 \%$ in 1996 to $8.60 \%$ in 2008 and a predicted 10.62\% in 2020. Employer health costs per worker are rising $5.77 \%$ a year versus total compensation growth of just $3.93 \%$ per year. To accommodate the outsize gain in health costs, wages must grow more slowly than compensation, causing wages to decline as a share of compensation from $81.38 \%$ in 1996 to $79.95 \%$ in 2008 and a predicted $78.18 \%$ in 2020 . The top panel results refer to earners with wages below the maximum taxable earnings amount, implying that both the FICA tax and the OASDI payroll tax are always $7.65 \%$ and $6.2 \%$, respectively, of the average employee wage. (Note that the table only contains our estimates of the employer contribution to FICA and OASDI as a fraction of compensation. These estimates must be doubled to show the combined employee and employer tax as a share of compensation.) The drop in the share of compensation that consists of money wages reduces the FICA and OASDI tax as a percentage of employee compensation. Under our alternative scenario, none of the components of employee compensation changes as a share of 
total compensation. Note that under the alternative scenario the FICA tax share increases $0.11 \%$ of employee compensation in 2008 and a predicted $0.24 \%$ of employee compensation in 2020 compared with our baseline assumptions. These results are straightforward, because all employee wages for this group of earners are subject to the same FICA and OASDI payroll tax rates. There are no employee earnings above the maximum taxable earnings cap.

Results in the second panel, which refer to workers with wages above the earnings cap, show a more complicated picture. Employer health costs are increasing 5.77\% a year, and total compensation costs are increasing $4.495 \%$ a year. Health costs are initially $2.06 \%$ of total compensation costs for these high wage workers, and this ratio increases under our baseline assumptions to $2.38 \%$ of compensation in 2006 and to $2.76 \%$ of compensation in 2020 . Both the FICA tax and OASDI payroll tax shrink as a percentage of compensation, in part because money wages are a declining percentage of compensation and in part because rising wage inequality increases the fraction of money wages above the taxable maximum amount. Under the alternative scenario employer health care costs increase at the same annual rate as compensation. In this case, however, money wages grow slightly faster than compensation. The reason is that FICA and OASDI taxes increase more slowly than compensation, since a smaller percentage of high-wage earners' wage income is below the taxable maximum earnings amount. Thus, even under the alternative assumption regarding employer insurance costs the percentage of compensation taxed by Social Security is expected to decline. In this case, however, the principal reason for the decline is the differential rate of compensation growth for workers above and below the taxable maximum amount. The rising inequality of compensation and wages causes a growing fraction of wage income to go untaxed because it is above the taxable maximum amount.

The bottom panel of Table 3 shows the combined results for workers with wages above and below the taxable wage cap. These reflect the weighted average results for the two groups of earners. Not surprisingly, both the FICA payroll tax and the OASDI payroll tax represent a shrinking share of employee compensation over time, even under the alternative assumption that employer health insurance costs per worker rise in proportion to overall compensation costs. Rising wage and inequality compensation will reduce the share of compensation paid out as FICA and OASDI taxes, even if employer health costs do not increase any faster than compensation. If health costs climb faster than overall compensation, FICA and OASDI taxes 
will fall even faster compared with compensation. More compensation will be received by wage earners as untaxed employee compensation; less will be received as money wages below the maximum taxed earnings amount. Compared with a labor market in which employer health costs increase proportionately with total compensation, a world with excess health cost increases will be one in which OASDI tax revenues are 1.64\% lower in 2008 and 3.70\% lower in 2020, assuming that total compensation payments are the same.

\section{Effect of health reform on the Social Security tax base}

So far we have analyzed trends in health care spending and employer insurance costs using the MEPS data for 1996-2008. We now extend the analysis to assess how the Affordable Care Act will affect the trend in average employer health contributions and the distribution of health contributions across workers. The extension focuses on shifts in compensation that may occur as a result of reform, in particular those shifts that will affect the amount of wages covered by Social Security.

The Patient Protection and Affordable Care Act, signed into law in March 2010, established a mandate for most legal U.S. residents to obtain health insurance or pay a penalty if they fail to do so. Among other things, the law called for creation of insurance exchanges within each state. In a state's exchange, individuals and small businesses can compare insurance premiums under competing plans and purchase an insurance policy. Families and individuals can obtain policies with a public subsidy if deemed eligible for one. In addition, the law significantly expands eligibility for Medicaid, and it establishes financial penalties for large firms that do not provide health insurance to their employees or that provide insurance at a cost that is found to be unaffordable.

These changes are expected to boost the percentage of the nonaged population covered by health insurance. The CBO predicts that uninsured adults and children will decline from 19\% to $7 \frac{1}{2} \%$ of the nonelderly population after the major provisions of the Affordable Care Act have been implemented. Many workers will see a shift in the source of their insurance as some obtain coverage through the exchanges and others obtain coverage under a new employer sponsored plan. When these shifts occur we assume some employers will alter their compensation package to reflect increases or reductions in their cost of providing insurance to their workers. To estimate the impact of the changes on the wages of individual workers, we assume that the total 
compensation received by each worker will be unaffected by the reform. ${ }^{6}$ An increase in the cost of providing insurance to a worker, either as a result of providing new coverage or paying a penalty for the failure to offer affordable coverage, will result in an equivalent reduction in the amount of money wages paid to the worker. A reduction in the cost of providing insurance because a previously insured worker obtains subsidized insurance through the exchanges or Medicaid will increase the amount of compensation paid as money wages. Our simulation does not attempt to model the impact of health reform on the underlying trend in health care costs. Instead, it models changes in the source of employee insurance coverage and the impact of these changes on employee compensation packages, especially on wage compensation that is taxable by Social Security.

We estimated the effects of the Affordable Care Act in 2016, when most of the law's provisions will be implemented in their final form. Our data for performing the simulation are taken from the MEPS household surveys for 2006 and 2008. The survey sample weights are adjusted to reflect the Census Bureau and Bureau of Labor Statistics projections of the gender and age groups of the civilian non-institutionalized population in 2016 . $^{7}$ We adjusted reported wage and income values in the MEPS files to reflect predicted wage and income increases through 2016. Health insurance premiums were also adjusted to reflect predicted growth in premiums through the same year.

Workers in the MEPS samples are initially divided into four categories based on their health insurance coverage in the year of their interview. Workers and their dependents can be covered by employer-provided insurance, by Medicaid or CHIP (Children's Health Insurance Program), or by nongroup and other insurance plans (including Medicare), or they can be uninsured. These are the four categories used by CBO to make estimates of the cost and effects

\footnotetext{
${ }^{6}$ Of course, the assumption will not be literally true. However, it is a defensible approximation of reality if on average and over the long run employers adjust their compensation packages to reduce money wages to workers who become more costly as a result of new health insurance obligations or become cheaper because the cost of subsidizing some employees' health insurance has been assumed by the government.

${ }^{7}$ By using data from both the 2006 and 2008 MEPS panels, we effectively double the number of observations available for the analysis. There is no overlap in the two samples, because each sample member is kept in the household survey for a maximum of two years.
} 
of the Affordable Care Act. ${ }^{8}$ Our simulation results closely match the CBO estimates of sources of insurance coverage both before and after implementation of reform (Table 4).

The first goal of the simulation is to determine the source of each worker's insurance after the implementation of reform. We specified five possible post-reform coverage categories. After the reforms are implemented workers and their dependents can be covered by employerprovided insurance, by Medicaid or CHIP, by nongroup and other insurance plans (including Medicare), or they can obtain potentially subsidized insurance through a state insurance exchange. Finally, they can remain uninsured. We assume that workers will ordinarily select the insurance option that is most financially advantageous for their families. Because employersponsored insurance is heavily subsidized by employers, employer coverage will usually be chosen by employees who work for employers that offer insurance. We assumed that any worker offered employer insurance in the 2006 and 2008 MEPS surveys would continue to be offered employer insurance after reform. However, Medicaid and CHIP are free for many households, and health reform will increase the number of low-income working families qualifying for Medicaid because the income eligibility limits for Medicaid will be increased. For workers and dependents who already receive insurance from this source, we assume their coverage under the program will continue. In the case of working families who become newly eligible for Medicaid, we assume that $80 \%$ will enroll in the program, even if they previously received insurance from an employer. ${ }^{9}$

It is also possible that employees who are not eligible for Medicaid will be offered subsidized coverage through a state insurance exchange that is less expensive than the insurance offered by their employers. We assume that some of these workers will switch their coverage from a (more expensive) employer plan to a (less expensive, subsidized) exchange policy. We assume, however, that workers currently covered under an employer plan would need to obtain premium savings of at least $20 \%$ before they would choose to give up an employer plan for a subsidized policy obtained through an exchange. Though the assumption may seem arbitrary, it attempts to reflect a basic reality. Behavioral inertia will predispose many workers to retain the

\footnotetext{
${ }^{8}$ Some MEPS respondents report multiple sources of insurance coverage. These were assigned a primary source of insurance based on coverage received during the longest portion of the year.

${ }^{9}$ After the implementation of health insurance reform in Massachusetts, 80 percent of the people who became newly eligible for Medicaid enrolled in the program (Sommers and Epstein 2010).
} 
insurance coverage they already have rather than search for cheaper alternatives. In order to make a comparison of net premiums we calculated the subsidized premium that workers would face if they obtained an insurance policy through an exchange. This requires a calculation of the likely cost of a group policy premium and the public subsidy for which the worker is eligible. The size of the subsidy is determined by the family's income, as specified in the reform law.

Finally, in the case of workers who were not offered insurance by their employers in the MEPS surveys we had to determine whether their employers would offer a group health plan after the implementation of reform and, if so, the cost of the plan to employees. This determination depends on the penalties the employer would face if no plan were offered to its workers and on the public subsidies it would receive if an employer plan were offered. Our assumption is that private establishments with 50 or more workers will offer group insurance plans, while establishments with fewer than 50 employees will only offer insurance if they offered insurance before the reform. The penalties on large employers will persuade most of them to establish plans covering their employees. We do not think the subsidies encouraging small employers to establish plans will materially change the percentage offering a company health plan. Details about how we determine the source of employees’ post-reform insurance coverage are described in the appendix.

After assigning workers to post-reform insurance, we estimated the impact of changes in insurance status on employee wages. The baseline wage of each worker is the annual wage reported in the MEPS surveys, converted into 2016 dollars. As already noted, we assume that any new health insurance premiums and any penalty for failure to offer an affordable health plan will be subtracted from an employee's wage. On the other hand, any savings in employer health premiums because workers leave an employer-sponsored plan will result in an increase in the employees' money wage. Thus, we assume the total compensation of each employee remains the same, but the division of employee compensation between wages and insurance premiums or penalties can change. For workers who continue to be covered under their employer's health plan, we assume there is no change in the employer's cost of providing coverage and hence no change in the wage. For workers who previously did not receive coverage under an employersponsored plan and who do not receive employer coverage after reform, there will only rarely be a change in their employers' health insurance cost. A change can only occur in the case of large employers who decline to offer an affordable health insurance plan to their employees. Those 
employers must pay a financial penalty for failing to offer an affordable health plan, and we treat the penalty as a subtraction from the compensation the employer is willing to pay to affected employees. ${ }^{10}$ For workers who begin to receive health insurance coverage under an employer plan, the new employer health insurance contribution must be subtracted from the worker's wage. For a worker who leaves an employer-sponsored plan, the employee can receive an increase in money wages equal to the reduction in employer health premiums less any penalty the employer may have to pay if the employee receives publicly subsidized insurance. ${ }^{11}$

Results. In our analysis we focus on Social Security-covered wages that are below the taxable wage ceiling, estimated to be $\$ 125,500$ in 2016 . There are two situations in which an employee’s wages will increase and several in which wages will decline. Employees’ wages will increase if they were enrolled in employer insurance before reform and then switch into (a) Medicaid or (b) an insurance plan obtained through a state exchange. Even if the employer must pay a penalty as a result of the switch, our calculations suggest that employers will typically spend less on the penalty than they would have spent to provide insurance coverage to workers switching out of the employer plan. Employees' wages will fall if they switch from uninsured status or from coverage under a nongroup plan into an employer-sponsored insurance policy. Our simulation model predicts the workers whose coverage status under an employer health plan changes and the resulting change in the employees' taxable wage.

Table 5 shows our basic simulation results. It displays our estimates of average money wages and aggregate Social Security-covered wages by wage decile. We find that reform will lead to an increase of money wages in the bottom six deciles, with covered wages increasing by as much as $4.3 \%$ in the bottom decile. The shift in compensation toward money wages occurs in part because many workers with modest earnings will become eligible for Medicaid. Workers who are currently insured by an employer plan and who switch to Medicaid coverage will no

${ }^{10}$ Our calculations exclude the effects of reform on 25 percent of public employees, selected at random from among the public employees in the MEPS household survey files. We make this exclusion because approximately one-quarter of public employees are not covered by Social Security.

${ }^{11}$ Employers with 50 or more full-time employees that offer health insurance coverage but have a full-time employee who obtains insurance through an exchange and receives a premium tax credit must pay the lesser of $\$ 3,000$ for each employee receiving a premium credit or $\$ 2,000$ for each full-time employee, excluding the first 30 employees from the assessment (Kaiser 2011). We assume that for many firms paying the $\$ 3,000$-per-employee penalty is more economical than paying $\$ 2,000$ for every full-time employee in the firm. In our simulation we therefore subtract a penalty of $\$ 3,000$ whenever an employer must pay a penalty as a result of a worker’s decision to obtain insurance through an exchange. 
longer receive part of their compensation in the form of an employer health contribution. Under our assumption, the part of compensation that formerly went to pay insurance premiums is now added to workers' money wages. In addition, many employer-insured workers in the lower part of the wage distribution are employed in small establishments. Small firms are not expected to pay penalties when employees shift from employer coverage into a health plan obtained in an insurance exchange. For example, among currently employed earners in the bottom wage decile, 60 percent of workers who switch from employer insurance to exchange-provided insurance are employed by small firms. Since these firms are unlikely to be fined when their workers obtain insurance outside the employer plan, the full amount of the premium is added to the wage. A smaller fraction of employer-insured workers in higher wage deciles are employed in small establishments. In the sixth decile only 38 percent of workers who switch from employer insurance to an exchange-provided policy work in small firms. The remaining 62 percent of workers are employed by employers that will probably have to pay a fine for each worker obtaining subsidized insurance. In the eighth decile, just 22 percent of workers who switch from employer-provided to exchange-provided insurance are employed by small firms that are unlikely to face fines.

Many employees in the lower ranks of the wage distribution work less than full time. The employers of part-time workers, whether large or small, do not pay fines when their employees obtain subsidized health policies through an exchange. (Part-time workers are defined as those who work 30 hours or less a week.) Because part-time work is much less common in the top wage deciles, it is less likely that employers of high-wage workers can avoid fines when their workers switch to an exchange-provided plan.

In contrast to the rise in money wages in the lower wage deciles, our findings show a small decline in wages in three of the top four deciles. Not surprisingly, there is virtually no predicted change in wage earnings in the top wage decile. In the top four deciles of the wage distribution we predict virtually no change in the source of insurance coverage for workers who were covered by an employer plan before reform (Figure 13). Only a very small percentage of employer-insured high-wage workers are predicted to obtain insurance through an insurance exchange. In many of these cases, the employer would be required to pay a penalty as a result of the switch. A small proportion of high-wage workers are not currently offered coverage under an employer-sponsored plan (see Figure 4). In the case of workers employed in large firms, we 
assume employers will begin offering health plans and many high-wage workers will enroll in the plans. The predicted premium their employer would pay to provide insurance would result in an equivalent reduction in wages. Because there is relatively little change in employer coverage in the top wage deciles, on average the changes cause very small percentage effects on workers' wages. Average money wages and aggregate Social Security-covered wages decline by small amounts in the top wage deciles.

The reductions in Social Security-covered wages in the top deciles are more than counterbalanced by increases in covered wages in the bottom six deciles. The net predicted effect of the Affordable Care Act is to boost total Social Security-covered wages by about $0.3 \%$. Thus, health insurance reform would produce only a very small impact on Social Security payroll tax receipts through its effects on the proportion of employee compensation that is paid as wages and as employer health premiums. From the results in the previous section it should be obvious that the more important potential effect of reform is on the trend rate of increase in health insurance costs and hence on employer health premiums. The simulation results in this section suggest that changes in health compensation arising from changes in the source of employees' insurance are likely to have only a small impact on the Social Security tax base.

\section{Conclusion}

Over the past six decades health care costs have increased much faster than employee compensation and other consumer prices. Over that same time span employers assumed a growing role in insuring their workers' health care expenses. The great majority of wage and salary workers and their dependents now receive health insurance through an employer-based plan. Even when the expansion of employer coverage ended and the liberalization of employer health plans ceased, employer outlays on workers' health consumption continued to grow as a result of increases in health care prices and utilization. These trends have important implications for the Social Security tax base. Money wages, but not employer contributions for health benefits, are included in taxable earnings. Under the assumption that workers ultimately bear the cost of employer-provided health benefits through lower wages, the continuing rapid growth in health costs reduces the share of employee compensation included in the tax base. In recent decades the outsize growth of health costs has been accompanied by a rise in wage and compensation inequality. Workers at the top of the wage distribution have seen faster increases in wages and compensation than workers in the middle and at the bottom of the distribution. 
Growing wage inequality also reduces the Social Security tax base, because it increases the proportion of wages above the taxable earnings ceiling.

This paper has examined the relationship between rising employer health costs and growing wage inequality using wage and insurance premium data in the MEPS household and employer survey files. During the years we analyze, 1996-2008, we find only modest changes in the insurance coverage of wage and salary workers and somewhat larger changes in the percentage of workers who opt for more costly, family plans. The proportion of workers enrolling in more costly plans fell in every wage decile. Nonetheless, employer outlays on employee health plans rose considerably faster than wages in every part of the wage distribution except among the bottom one-tenth of wage earners. In the top $80 \%$ of the wage distribution, we find that employer contributions for employee health plans increased at approximately the same rate. However, employer health premiums represent a larger percentage of total compensation in the middle and near the bottom of the distribution than they do at the top. Consequently, the growth in employer health costs absorbed a larger percentage of compensation gains in the middle and at the bottom of the wage distribution - except at the very bottom - compared with the top of the distribution. Differences in the rate of growth of wages tended to reinforce this differential effect of rising health costs. Wages grew faster at the top of the distribution, especially above the Social Security taxable wage ceiling, compared with the middle and bottom of the distribution. In simulations we find that the combined effect of rising health costs and increasing inequality was to reduce significantly the share of Social Security-taxable wages in employee compensation. Taking the rise in compensation inequality as a given, the increase in employer health costs significantly reduced the share of compensation included in the Social Security tax base. If employer health costs had increased at the same rate as overall compensation, the 2008 Social Security tax base would have been 1.7\% larger. We project that the tax base would be 3.8\% larger by 2020 if employer health costs grew between 1996 and 2020 at the same rate as employee compensation.

In estimating the potential effects of the Affordable Care Act on money wages and the Social Security tax base we ignore the potential effects of the law on the trend in overall health costs. We take this trend as given and estimate the impact of reform on the sources of employee health insurance coverage. Under the maintained assumption that total employee compensation will remain unchanged, we then trace the effects of changes in the source of health coverage on 
the division of employee compensation between money wages and employer contributions for health insurance. On balance we find that health reform is likely to increase employee compensation in the Social Security tax base. The main reason is that some employers of lowand middle-wage workers are likely to see some of their employees switch into subsidized insurance plans provided through health insurance exchanges. Because these employers will be relieved of the burden of contributing as much to their group health plans, they will be able to offer higher wages to affected employees. To be sure, some employers will begin to offer health insurance because doing so will be less expensive than paying fines specified in the reform law. These employers will have to reduce money wages to compensate for their higher health care costs. Averaging across all workers, however, the money wage increases received by employees who impose lower health costs on their employers are likely to more than offset the higher health contributions for workers who gain access to an employer-sponsored health plan. The net effect on Social Security-taxable wages is likely to be small.

The more profound effect of health reform on taxable employee compensation is likely to occur through a different channel. If insurance reform leads to slower long-term growth in health care spending, a larger fraction of future compensation will take the form of money wages. 


\section{APPENDIX: Assignment of workers to post-reform health coverage}

Each worker must be assigned a source of insurance or to uninsured status in the postreform period. There are five possible sources of insurance: (1) Medicaid and CHIP; (2) Employer-sponsored insurance; (3) Nongroup and other insurance (including Medicare); (4) A policy obtained through the state insurance exchange; and (5) Uninsured. Workers and worker dependents who were already enrolled in Medicaid or CHIP before reform were assumed to remain in Medicaid or CHIP. The new law raises the income cutoff for Medicaid to 133 percent of the poverty line, so it is unlikely that any person currently covered by the program would lose eligibility. Among workers and worker dependents who become newly eligible for Medicaid as a result of the higher income limit, we assume $80 \%$ will enroll in Medicaid. We use random assignment to determine the $80 \%$ who will enroll.

Workers covered by employer insurance before reform will have three coverage options: take up Medicaid, obtain insurance through a state exchange, or remain in the employersponsored plan. Workers with employer insurance before reform who were not eligible for Medicaid, or who were in the $20 \%$ eligible but not randomly assigned to be newly enrolled in Medicaid, were assumed to be offered an employer-sponsored plan after reform. To determine which option is selected, we calculated the premium that each worker would have to pay if they obtained insurance through an exchange. The net premium depends on workers' incomes and their eligibility for subsidies. We then compared this calculated premium with the one the worker pays for their current employer coverage. We assume that the exchange premium must be at least $20 \%$ cheaper than the worker's current premium before a worker would switch out of his or her current employer-sponsored plan.

Workers covered by a nongroup or other insurance plan before reform have up to four potential sources of coverage after reform: take up Medicaid, obtain insurance through a state exchange, enroll in an employer-sponsored plan, or remain covered by the nongroup or other insurance plan. We enrolled most workers newly eligible for Medicaid into that insurance plan using the procedures already described. For the remainder of workers we calculated the premium that each worker would have to pay if they obtained insurance through an exchange. After reform, some workers will be offered employer insurance who were not offered insurance before reform. For those workers whose employers will offer a group health plan, we calculate their expected employer-sponsored insurance premium as the average U.S. premium facing 
workers in an employer-sponsored plan. ${ }^{12}$ We then compare the premium a person currently pays for their nongroup insurance with the premium they would pay under the exchange and the premium they would pay if they were offered employer insurance. Most workers are assigned to the least expensive option. However, we assume that workers will only switch out of their present coverage if the selected alternative option is at least $20 \%$ cheaper than their current nongroup insurance plan.

For workers who are uninsured before reform, there are also up to four post-reform coverage options: take up Medicaid, obtain insurance through a state exchange, enroll in an employer-sponsored plan, or remain uninsured. As before, we assign some of these workers to Medicaid based on their income, and predict for each worker a potential exchange premium and a potential employer premium if their employer is assumed to offer insurance. ${ }^{13}$ In order to encourage take up of health insurance, the new law stipulates that workers who choose to remain uninsured must pay a penalty based on their income and family size. In our simulation all workers are assigned the penalty they would have to pay if they choose to remain uninsured. The penalty is based on family size and income. We compare this penalty with the net premium workers would pay for insurance obtained through an exchange and the predicted premium for employer insurance (if it is offered). We assigned workers to the coverage category with the lowest cost to the worker.

${ }^{12}$ We assume that all workers employed in large private establishments (50 or more workers) will be offered insurance. We assume that the only workers in small private establishments who will be offered employer health plans are those who are currently offered a health plan by their employers. Up to 2016 firms with fewer than 25 employees will be entitled to receive a subsidy for offering a plan, providing an incentive for them to offer health insurance. However, beginning in 2016 the subsidy will end. Our assumptions about large- and small-firm insurance offers are consistent with Urban Institute predictions about the effect of reform on employer insurance offers (Garrett and Buettgens 2011).

${ }^{13}$ In the case of the uninsured, some were offered employer insurance before and chose not to take it. We assume they are still offered that insurance plan. Other uninsured workers are not offered an employer plan before reform. Again, we assume that all employees of private establishments with 50 or more employees will offer insurance coverage after reform, but the only small firms that offer insurance are ones that already offer insurance to their workers. 


\section{References}

Autor, David H. 2010. The Polarization of Job Opportunities in the U.S. Labor Market Implications for Employment and Earnings, Center for American Progress and Hamilton Project, Washington, D.C..

Bernard, Didem, and Jessica S. Banthin. 2007. "Family-Level Expenditures on Health Care and Insurance Premiums among the U.S. Nonelderly Population, 2004.” Research Findings No. 26. Rockville, MD: Agency for Healthcare Research and Quality.

Blumberg, Linda J. 1999. “Perspective: Who Pays For Employer-Sponsored Health Insurance?” Health Affairs 18(6) (November), pp. 58-61.

Burtless, Gary, and Pavel Svaton. 2010. "Health Care, Health Insurance, and the Distribution of American Incomes,” Forum for Health Economics \& Policy 13(1), p. 1-39.

Crimmel, B.L. 2009a. Premiums, Employer Costs, and Employee Contributions for Private Sector Employer-Sponsored Health Insurance, Family Coverage by Firm Size, 19962006. Statistical Brief \#230. (January 2009) Agency for Healthcare Research and Quality, Rockville, MD.

. 2009b. Premiums, Employer Costs, and Employee Contributions for Private Sector Employer-Sponsored Health Insurance, Single Coverage by Firm Size, 1996-2006. Statistical Brief \#231. (January 2009) Agency for Healthcare Research and Quality, Rockville, MD.

Garrett, Browen and Matthew Buettgens. 2011. "Employer-Sponsored Insurance under Health Reform: Reports of its Demise are Premature.” Urban Institute. Washington, DC.

Gruber, Jonathan. 2000. "Health Insurance and the Labor Market”. In A. Culyer and J. Newhouse, eds., Handbook of Health Economics, Volume 1, Amsterdam: Elsevier, pp. 645-706.

Jensen, G. A. and M. A. Morrisey. 2001. "Endogenous Fringe Benefits, Compensating Wage Differentials and Older Workers," International Journal of Health Care Finance and Economics 1 (3/4) (September-December), pp. 203-226.

Kaiser Family Foundation. 2011. "Focus on Health Reform: Summary of New Health Reform Law.” April 15. http://www.kff.org/healthreform/upload/8061.pdf

Pierce, Brooks. 2010. "Recent Trends in Compensation Inequality.” In K.G. Abraham, J.R. Spletzer, and M. Harper, eds., Labor in the New Economy. Chicago: University of Chicago Press, pp. 63-98.

Sing, Merrile, Jessica S. Banthin, Thomas M. Selden, Cathy A. Cowan, and Sean P. Keehan. 2006. "Reconciling Medical Expenditure Estimates from the MEPS and NHEA, 2002." Health Care Financing Review 28(1) (Fall), pp. 25-40.

Sommers, Benjamin D. and Arnold M. Epstein. 2010. "Medicaid Expansion - The Soft Underbelly of Health Care Reform?” New England Journal of Medicine 363 (November), pp. 2085-2087. 
Technical Panel on Assumptions and Methods. 2007. Report to the Social Security Advisory Board. Washington, DC: Social Security Administration.

U.S. Congressional Budget Office. 2009. Letter to Senator Bayh, "An Analysis of Health Insurance Premiums under the Patient Protection and Affordable Care Act" (November 30, 2009). Washington, DC: CBO.

. 2010. “CBO’s March 2011 Estimate of the Effects of the Insurance Coverage Provisions Contained in the Patient Protection and Affordable Care Act (Public Law 111148) and the Health Care and Education Reconciliation Act of 2010 (P.L. 111-152)" (March 18, 2011). Washington, DC: CBO. http://www.cbo.gov/budget/factsheets/2011b/HealthInsuranceProvisions.pdf 
Table 1. Employer-Sponsored Health Insurance Offer Rates, Take-up Rates, and Final Participation Rates by Wage Decile, 1996-1997 and 2007-2008

Percent of workers

\begin{tabular}{|c|c|c|c|c|c|c|}
\hline \multirow{2}{*}{$\begin{array}{l}\text { Tenth of } \\
\text { annual } \\
\text { wage } \\
\text { distribution }\end{array}$} & \multicolumn{2}{|c|}{$\begin{array}{l}\text { Health insurance } \\
\text { offer rate }\end{array}$} & \multicolumn{2}{|c|}{$\begin{array}{l}\text { Health insurance } \\
\text { take-up rate }\end{array}$} & \multicolumn{2}{|c|}{$\begin{array}{l}\text { Final participation } \\
\text { rate in insurance }\end{array}$} \\
\hline & $\begin{array}{l}1996- \\
1997\end{array}$ & $\begin{array}{l}2007- \\
2008\end{array}$ & $\begin{array}{l}1996- \\
1997\end{array}$ & $\begin{array}{l}2007- \\
2008\end{array}$ & $\begin{array}{l}1996- \\
1997\end{array}$ & $\begin{array}{l}2007- \\
2008\end{array}$ \\
\hline Bottom & 20 & 22 & 58 & 37 & 12 & 8 \\
\hline 2 & 30 & 43 & 64 & 56 & 19 & 24 \\
\hline 3 & 52 & 58 & 75 & 71 & 39 & 41 \\
\hline 4 & 67 & 69 & 84 & 80 & 56 & 55 \\
\hline 5 & 77 & 76 & 85 & 84 & 65 & 64 \\
\hline 6 & 84 & 83 & 87 & 88 & 73 & 73 \\
\hline 7 & 88 & 85 & 89 & 90 & 79 & 76 \\
\hline 8 & 89 & 87 & 89 & 92 & 79 & 80 \\
\hline 9 & 89 & 90 & 93 & 92 & 83 & 83 \\
\hline Top & 92 & 90 & 92 & 93 & 85 & 84 \\
\hline All & 69 & 70 & 86 & 84 & 59 & 59 \\
\hline
\end{tabular}

Note: The "offer rate" is the percentage of workers who are offered enrollment in a health plan by their employers; the "take-up rate" is the percent of workers offered enrollment who enroll in the plan; and the "final participation rate" is the percent of all workers in a decile that actually participates in their employer's plan.

Source: Authors' tabulations of 1996, 1997, 2007, and 2008 MEPS household surveys as explained in text. 
Table 2. Excess Reimbursement Received by Insured Workers as a Share of Estimated Employer Premiums, by Wage Decile, 1996-2008

\begin{tabular}{|c|c|c|c|c|}
\hline \multirow{2}{*}{$\begin{array}{c}\text { Tenth of annual } \\
\text { wage } \\
\text { distribution }\end{array}$} & \multicolumn{4}{|c|}{ Years } \\
\hline & 1996-1998 & 2001-2003 & 2007-2008 & 1996-2008 \\
\hline Bottom & 58 & 43 & 45 & 58 \\
\hline 2 & 50 & 47 & 63 & 48 \\
\hline 3 & 54 & 35 & 38 & 41 \\
\hline 4 & 45 & 38 & 32 & 38 \\
\hline 5 & 45 & 46 & 44 & 43 \\
\hline 6 & 38 & 35 & 47 & 41 \\
\hline 7 & 46 & 39 & 38 & 42 \\
\hline 8 & 65 & 41 & 42 & 46 \\
\hline 9 & 47 & 45 & 40 & 45 \\
\hline Top & 60 & 47 & 52 & 54 \\
\hline All & 51 & 42 & 43 & 45 \\
\hline
\end{tabular}

Note: "Excess reimbursement" is health reimbursement received by covered workers and their dependents less employee insurance premium payments for employer-sponsored insurance. Employer premiums are estimated employer contributions for employee group health plans.

Source: Authors' tabulations of 1996-2008 MEPS household surveys as explained in text. 
Table 3. Simulated Effects of Rising Employer Health Costs on Components of Compensation, 1996-2008

Percent of compensation

\begin{tabular}{ccrrr}
\hline Compensation & Wages & $\begin{array}{r}\text { Health } \\
\text { cost }\end{array}$ & $\begin{array}{r}\text { Employer } \\
\text { portion of } \\
\text { FICA tax }\end{array}$ & $\begin{array}{c}\text { Employer } \\
\text { portion of } \\
\text { OASDI tax }\end{array}$ \\
\hline \hline
\end{tabular}

Baseline: Rising health

costs

$\begin{array}{lrrrrr}\mathbf{1 9 9 6} & 100 & 81.38 & 6.97 & 6.23 & 5.05 \\ \mathbf{2 0 0 8} & 100 & 79.95 & 8.60 & 6.12 & 4.96 \\ \mathbf{2 0 2 0} & 100 & 78.18 & 10.62 & 5.98 & 4.85\end{array}$

Alternative: Stable health costs

$\begin{array}{llllll}\mathbf{1 9 9 6} & 100 & 81.38 & 6.97 & 6.23 & 5.05 \\ \mathbf{2 0 0 8} & 100 & 81.38 & 6.97 & 6.23 & 5.05 \\ \mathbf{2 0 2 0} & 100 & 81.38 & 6.97 & 6.23 & 5.05\end{array}$

Difference

$\begin{array}{llrrrr}1996 & --- & 0.00 & 0.00 & 0.00 & 0.00 \\ 2008 & --- & 1.43 & -1.63 & 0.11 & 0.09 \\ 2020 & --- & 3.19 & -3.65 & 0.24 & 0.20\end{array}$

Earners above taxable maximum amount

Baseline: Rising health costs

$\begin{array}{llllll}\mathbf{1 9 9 6} & 100 & 87.89 & 2.06 & 4.18 & 2.91 \\ \mathbf{2 0 0 8} & 100 & 87.75 & 2.38 & 4.01 & 2.74 \\ \mathbf{2 0 2 0} & 100 & 87.55 & 2.76 & 3.85 & 2.58\end{array}$

Alternative: Stable health costs

$\begin{array}{llllll}\mathbf{1 9 9 6} & 100 & 87.89 & 2.06 & 4.18 & 2.91 \\ \mathbf{2 0 0 8} & 100 & 88.02 & 2.06 & 4.05 & 2.77 \\ \mathbf{2 0 2 0} & 100 & 88.13 & 2.06 & 3.93 & 2.65\end{array}$

\section{Difference}

$\begin{array}{llrrrr}1996 & --- & 0.00 & 0.00 & 0.00 & 0.00 \\ 2008 & --- & 0.27 & -0.32 & 0.03 & 0.03 \\ 2020 & --- & 0.58 & -0.70 & 0.08 & 0.07\end{array}$

All earners

Baseline: Rising health

costs

$\begin{array}{llllll}\mathbf{1 9 9 6} & 100 & 83.08 & 5.69 & 5.69 & 4.49 \\ \mathbf{2 0 0 8} & 100 & 82.09 & 6.90 & 5.54 & 4.35 \\ \mathbf{2 0 2 0} & 100 & 80.87 & 8.36 & 5.37 & 4.20\end{array}$

Alternative: Stable health costs

$\begin{array}{llllll}1996 & 100 & 83.08 & 5.69 & 5.69 & 4.49\end{array}$




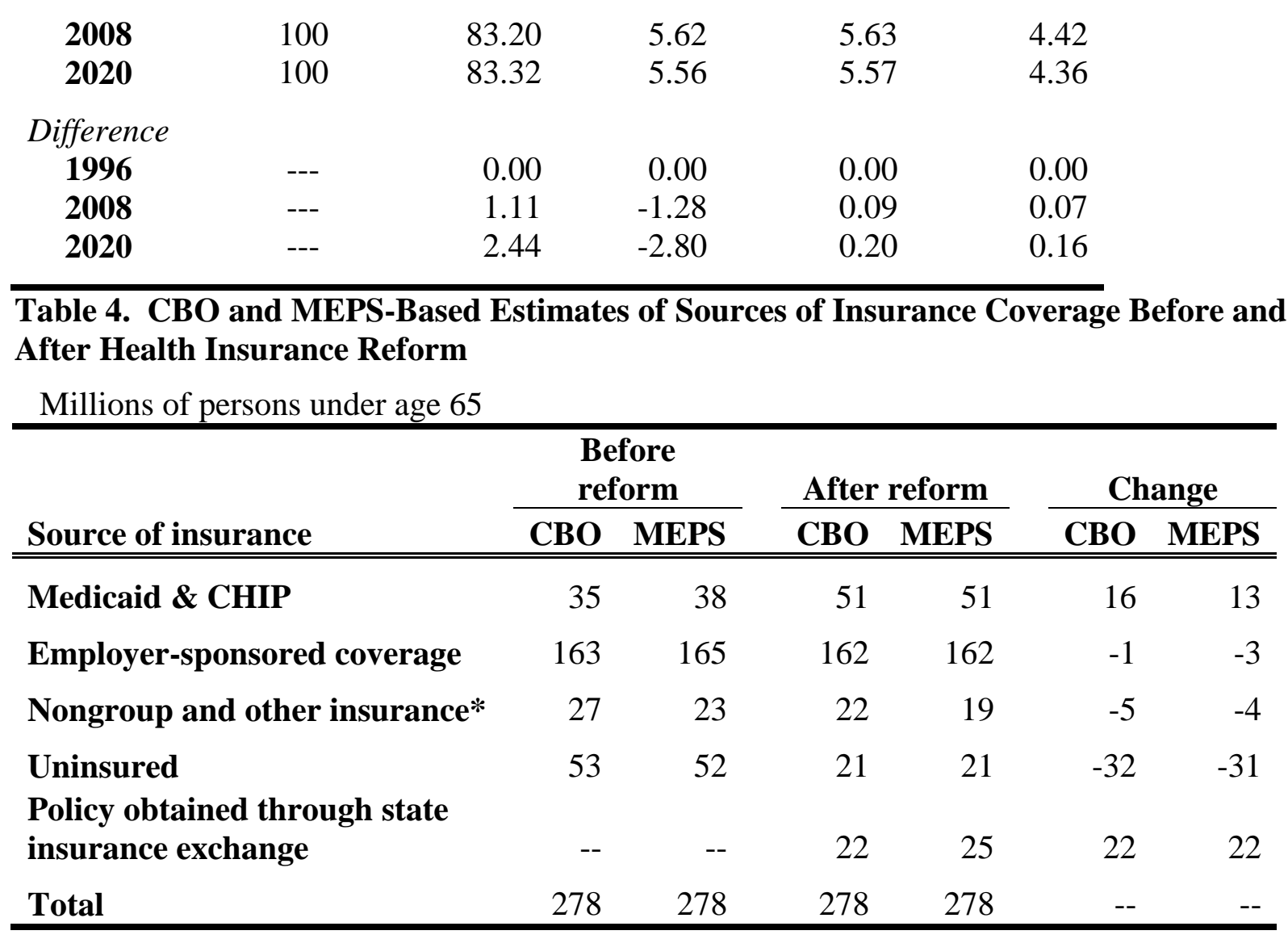

* "Nongroup and other insurance" includes coverage under Medicare.

Source: U.S. Congressional Budget Office and authors' tabulations of 2006 and 2008 MEPS household and averaged employer survey files as explained in text. 
Table 5. Simulated Effect of the Affordable Care Act on Social Security-Covered Wages by Wage Decile, 2016

\begin{tabular}{|c|c|c|c|c|c|c|}
\hline $\begin{array}{l}\text { Wage } \\
\text { decile } \\
\end{array}$ & $\begin{array}{c}\text { Average } \\
\text { wage } \\
\text { before } \\
\text { reform } \\
(1) \\
\end{array}$ & $\begin{array}{l}\text { Average } \\
\text { wage } \\
\text { after } \\
\text { reform } \\
(2) \\
\end{array}$ & $\begin{array}{c}\text { Aggregate } \\
\text { covered } \\
\text { wages before } \\
\text { reform } \\
\text { (billions) } \\
(3) \\
\end{array}$ & $\begin{array}{c}\text { Aggregate } \\
\text { covered wages } \\
\text { after reform } \\
\text { (billions) } \\
(4) \\
\end{array}$ & $\begin{array}{l}\text { Change in } \\
\text { covered } \\
\text { wages } \\
\text { (billions) } \\
(4)-(3) \\
\end{array}$ & $\begin{array}{c}\text { Change in } \\
\text { covered } \\
\text { wages } \\
\text { (percent) } \\
{[(4)-(3)] /} \\
(3) \\
\end{array}$ \\
\hline Bottom & $\$ 5,223$ & $\$ 5,448$ & $\$ \$ 78$ & $\$ 82$ & $\$ 3.4$ & 4.3 \\
\hline 2 & 13,085 & 13,483 & 196 & 202 & 6.0 & 3.0 \\
\hline 3 & 20,306 & 20,649 & 304 & 310 & 5.1 & 1.7 \\
\hline 4 & 26,998 & 27,345 & 405 & 410 & 5.2 & 1.3 \\
\hline 5 & 34,382 & 34,535 & 515 & 518 & 2.3 & 0.4 \\
\hline 6 & 42,063 & 42,146 & 630 & 631 & 1.2 & 0.2 \\
\hline 7 & 50,654 & 50,586 & 759 & 758 & -1.0 & -0.1 \\
\hline 8 & 62,668 & 62,646 & 939 & 939 & -0.3 & -0.0 \\
\hline 9 & 79,067 & 79,016 & 1,185 & 1,184 & -0.8 & -0.1 \\
\hline Top & 112,677 & 112,681 & 1,688 & 1,689 & 0.1 & 0.0 \\
\hline Total & $\$ 44,712$ & $\$ 44,854$ & $\$ 6,700$ & $\$ 6,722$ & $\$ 21.2$ & 0.3 \\
\hline
\end{tabular}

Source: Authors' calculations using MEPS household and employer survey data as explained in text. 


\section{Figure 1. Employer Nonwage Contributions as a Percent of Employee Compensation, 1950-2010}

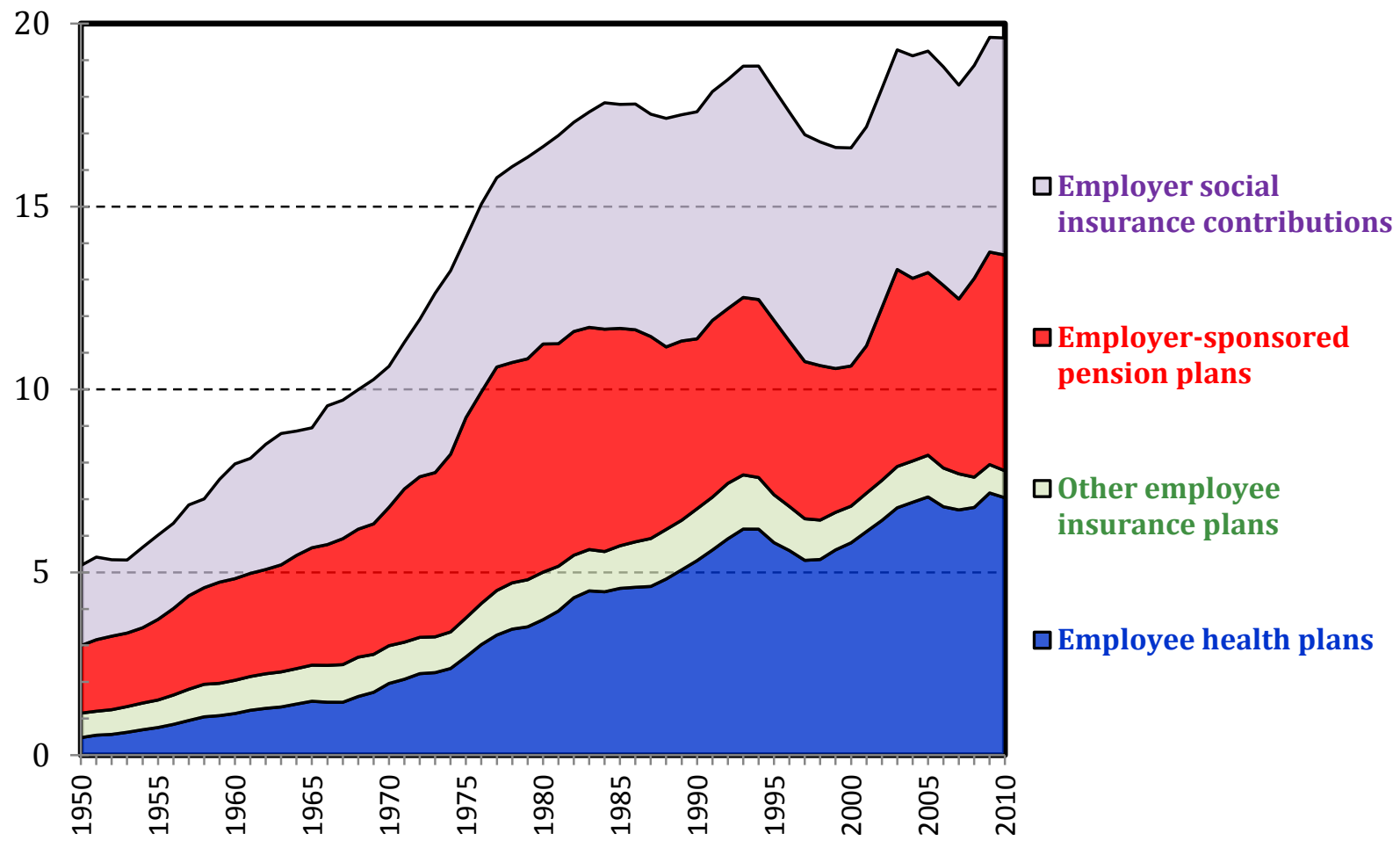

Source: U.S. Department of Commerce, Bureau of Economic Analysis, National Income and Product Accounts. 
Figure 2. Wage Developments Affecting the Trend in Compensation Taxed by Social Security, 1960-2009

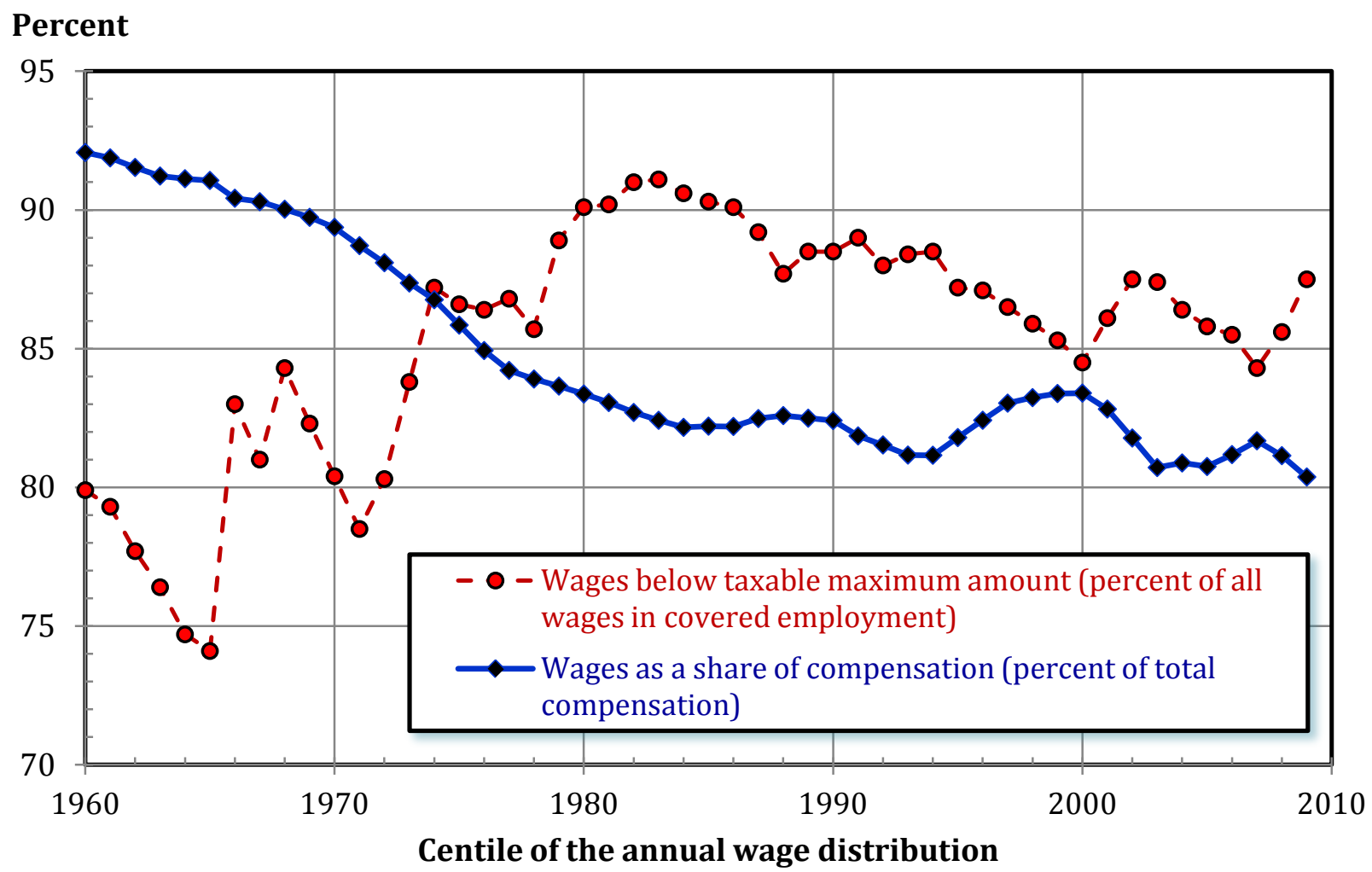

Source: U.S. Department of Commerce, Bureau of Economic Analysis, National Income and Product Accounts; Social Security Administration, various years, Annual Statistical Supplement to the Social Security Bulletin. 


\section{Figure 3. Average Premium Cost for Single and Family Coverage in}

Employer-Sponsored Insurance Plans at Private Firms, 1996-2009

\section{Current dollars}

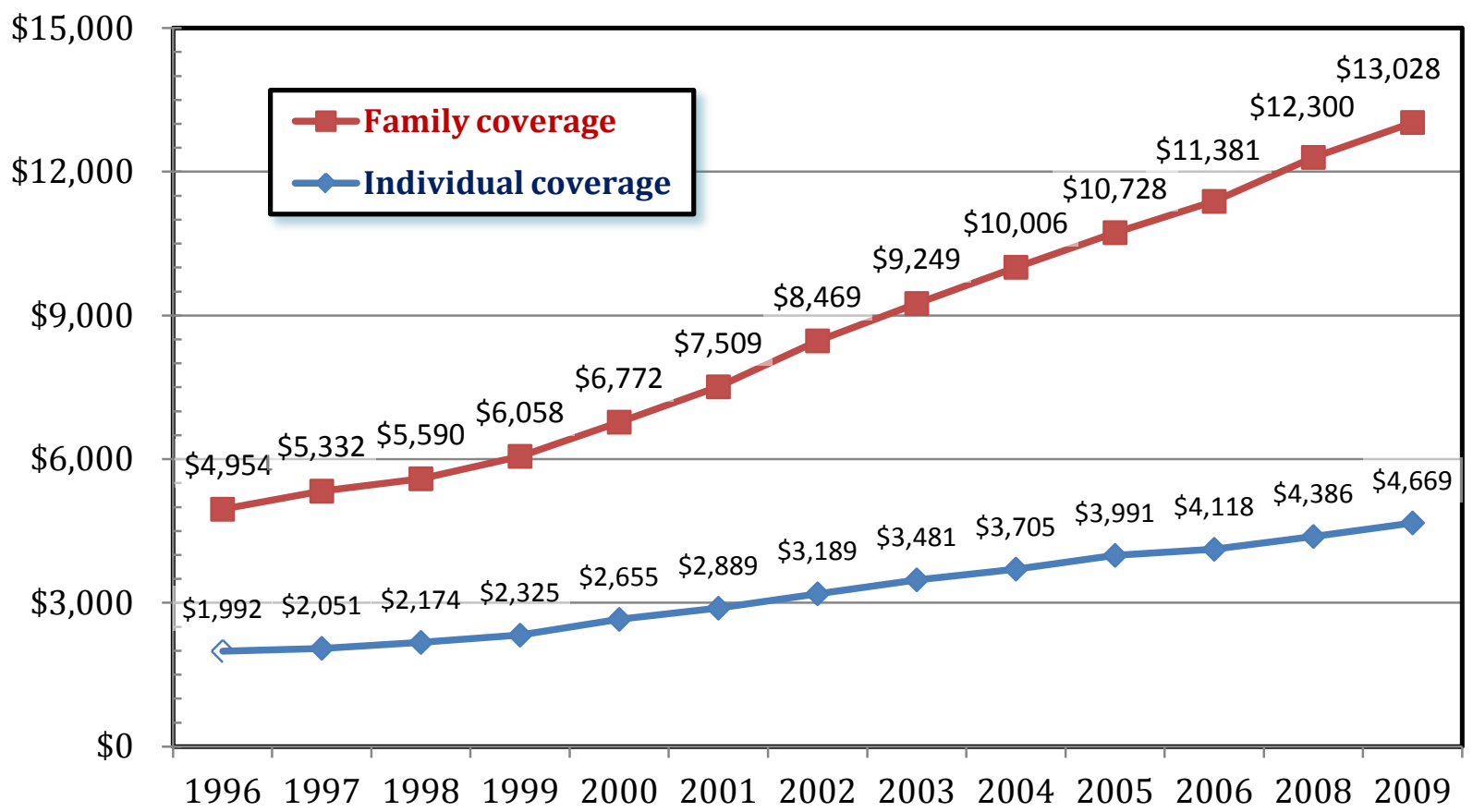

Note: MEPS employer survey results are not available for 2007.

Source: MEPS employer surveys, 1996-2009. 
Figure 4. Health Insurance Offer Rates and Participation Rates by Wage Decile, 1996-97 and 2007-2008

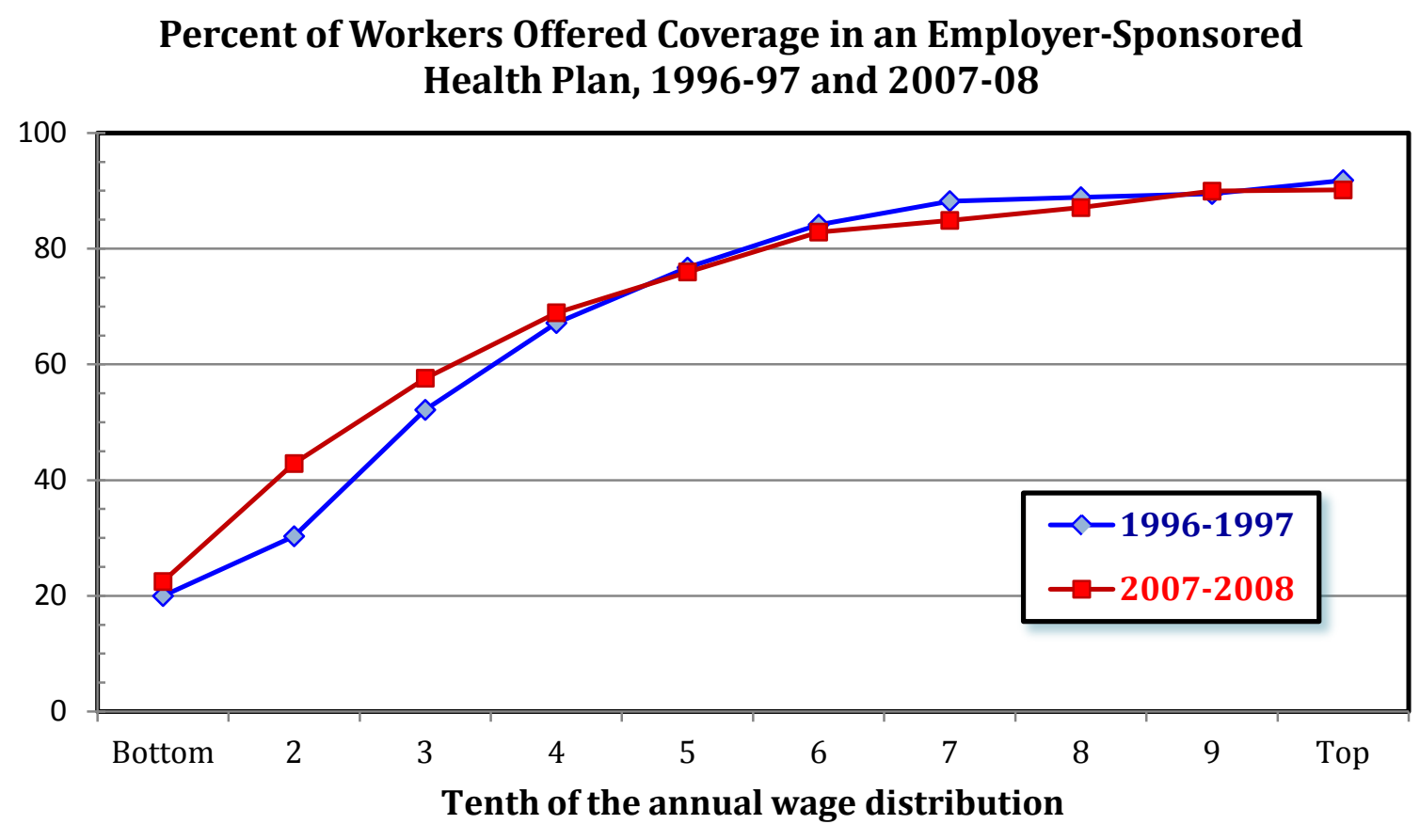

Percent of Workers Enrolled in an Employer-Sponsored Health Plan, 1996-97 and 2007-08 $\underline{\text { a }}$ /

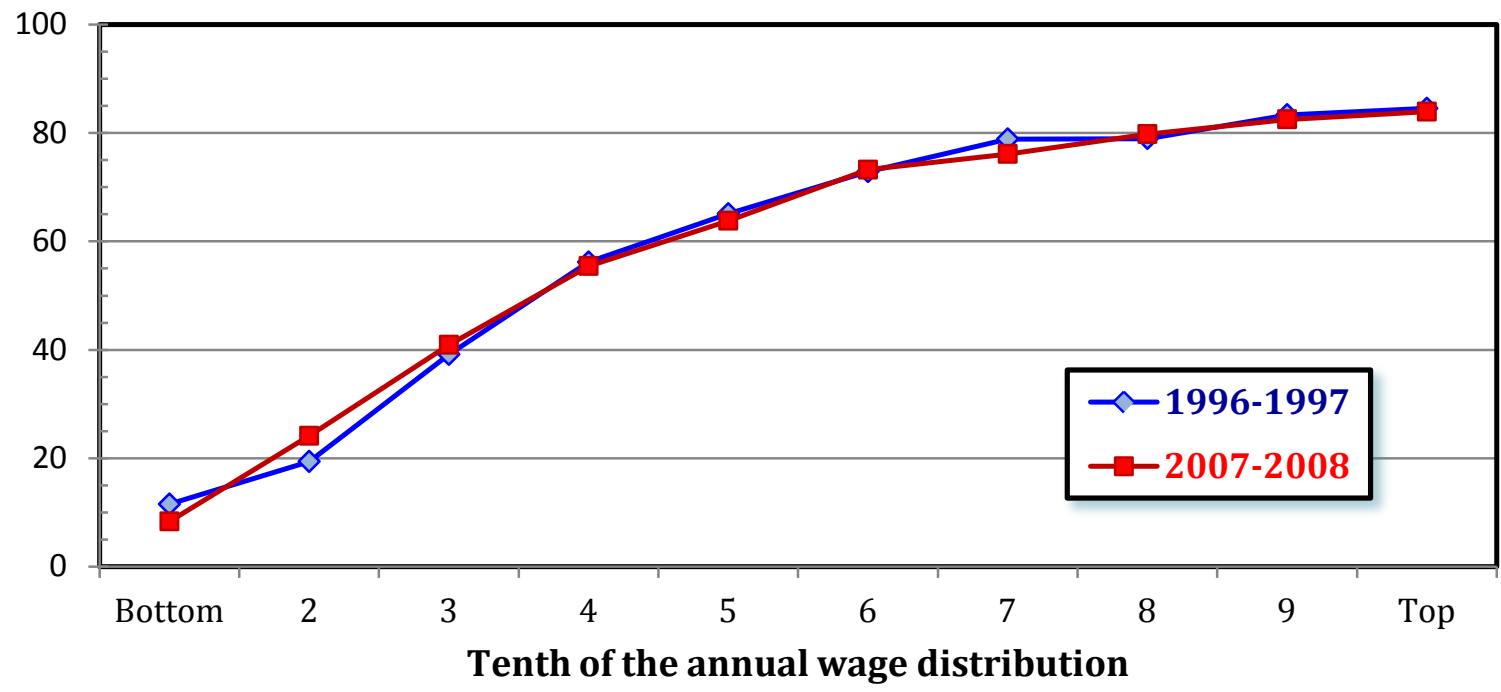

a/ Workers may be enrolled in either an individual or family plan as the principal insured person.

Source: Authors’ tabulations of 1996-2008 MEPS household survey files. 
Figure 5. Percent of Workers Enrolled in an EmployerSponsored Family Health Plan, 1996-97 and 2007-08 $\underline{a} /$

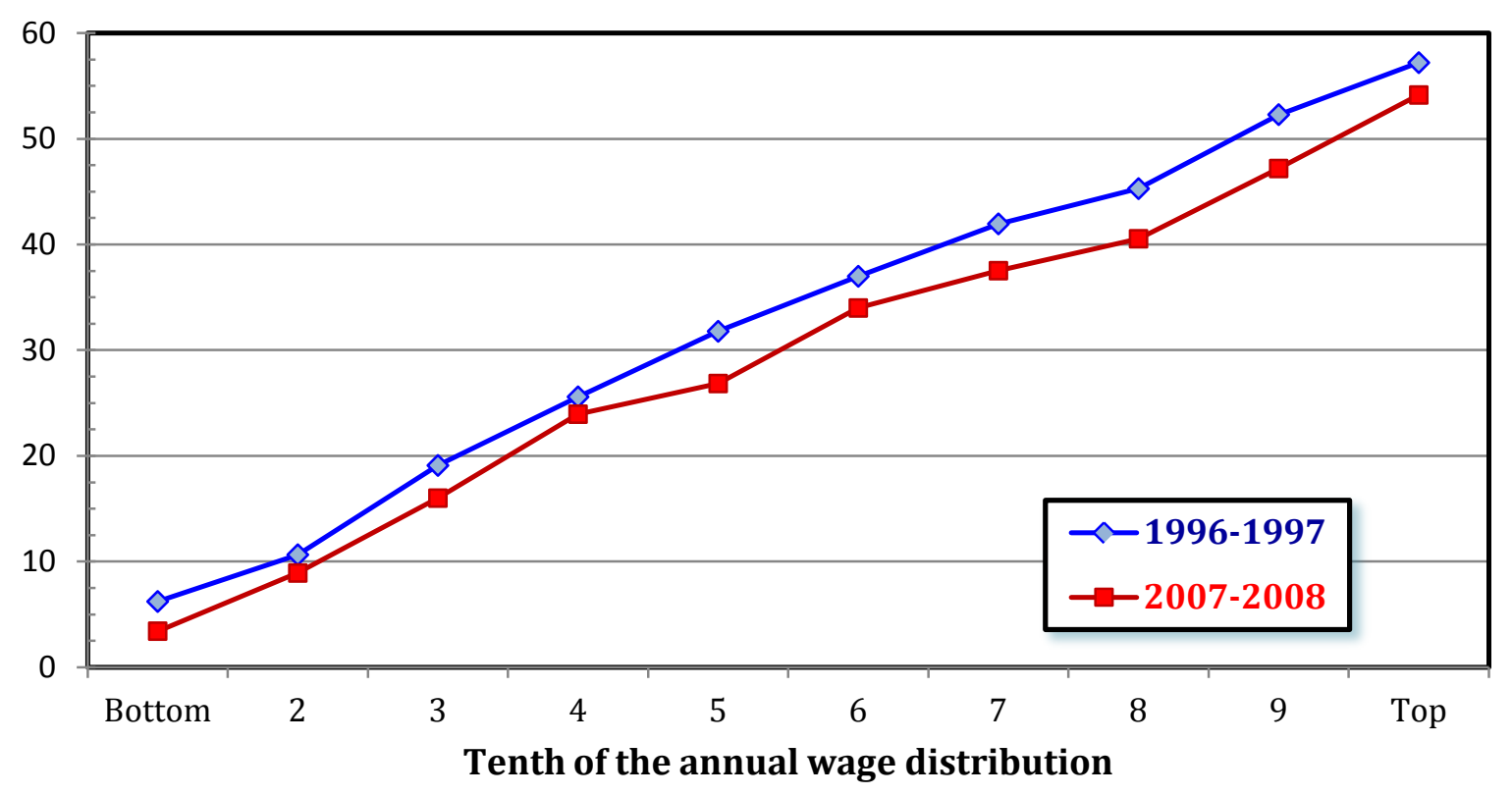

a/ Workers are enrolled in a family or employee-plus-one plan as the principal insured person.

Source: Authors’ tabulations of 1996-2008 MEPS household survey files. 


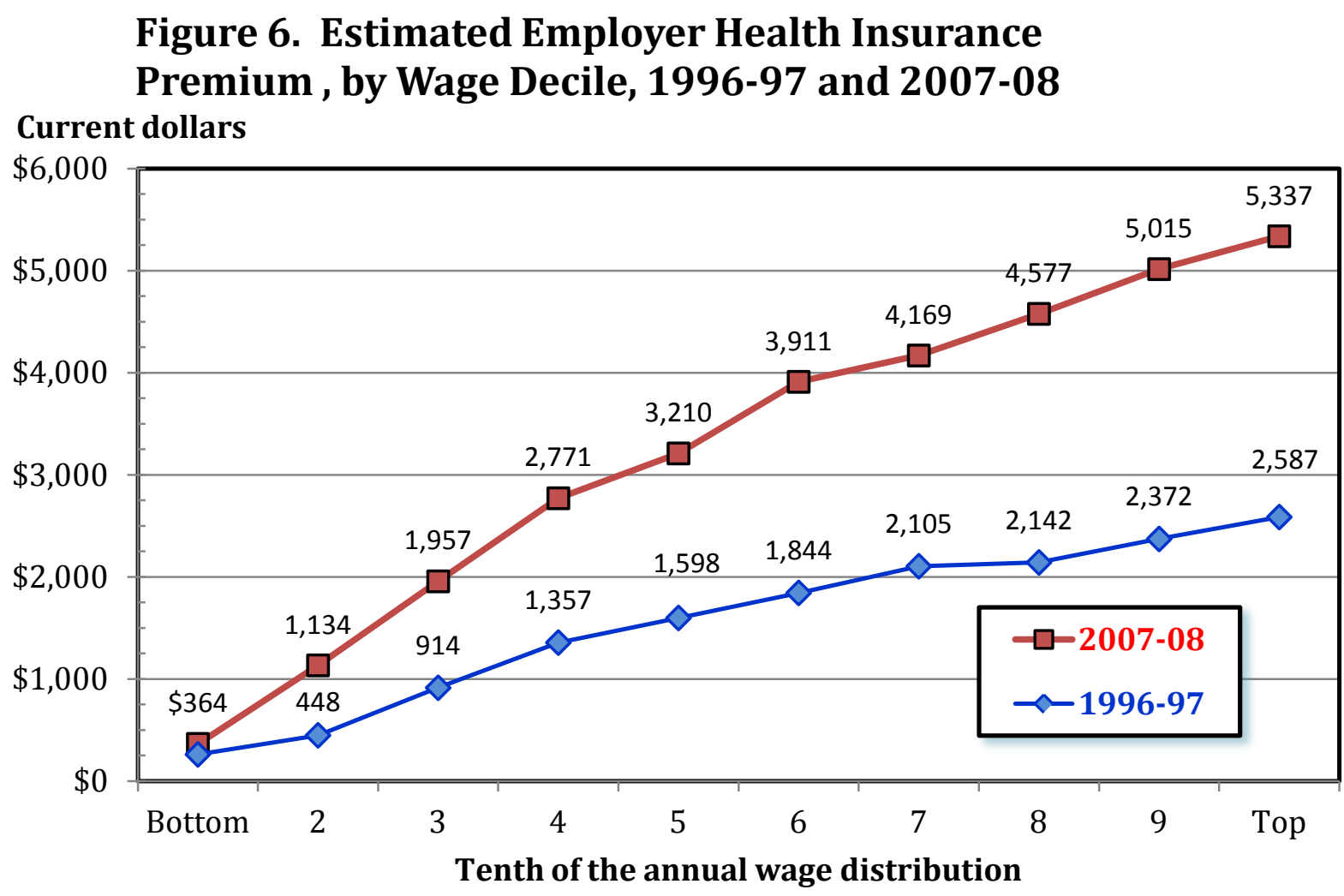

Note: Estimated employer premiums represent the average employer-paid premium for all workers in a wage decile, including workers who are not insured or even offered coverage under their employer's plan.

Source: Authors' tabulations of 1996-2008 MEPS household survey files and MEPS employer survey. 
Figure 7. Employer Health Insurance Premium as a Percent of Average Annual Wage, by Wage Centile, 1996-97 and 20072008

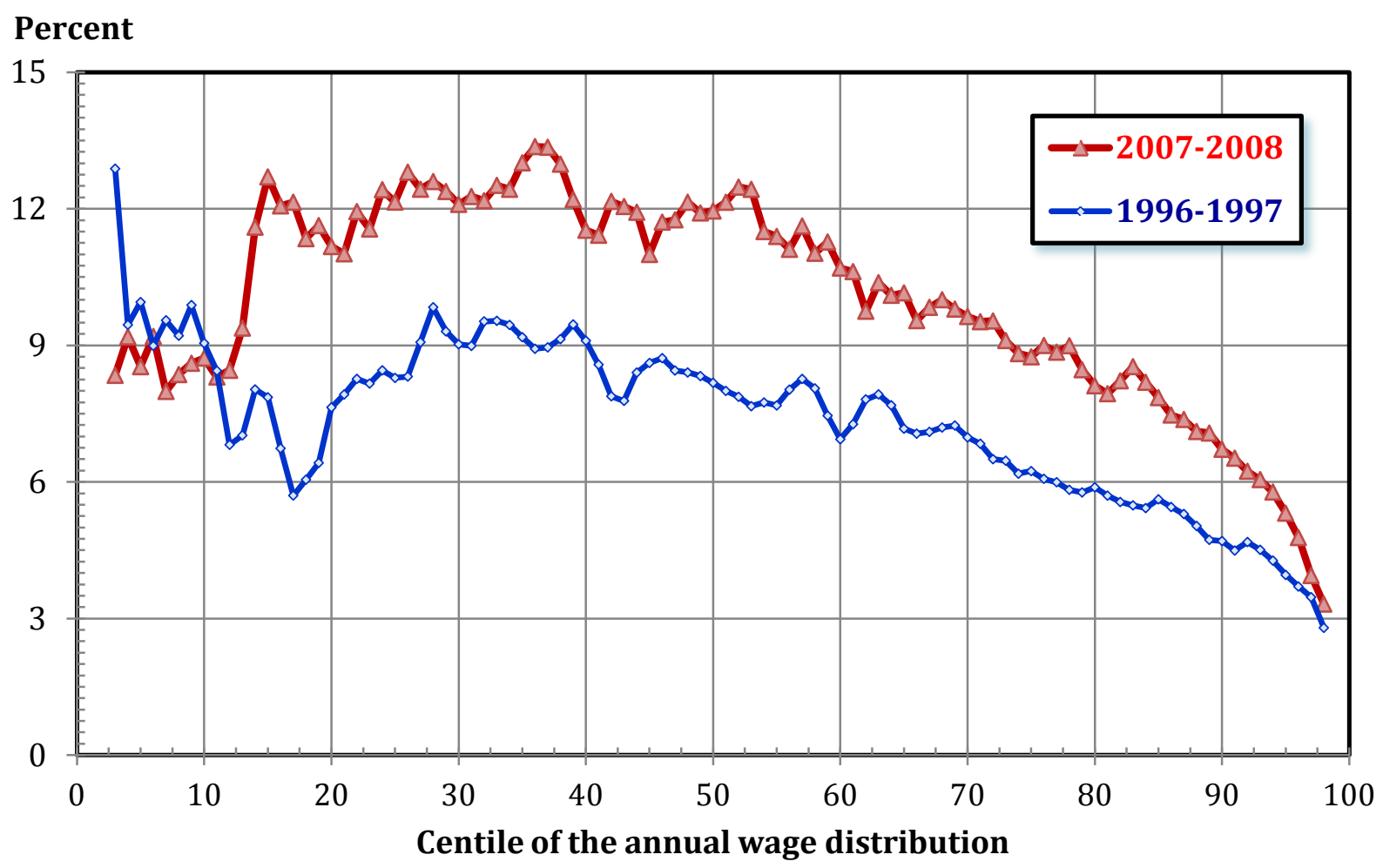

Note: Estimated employer premiums represent the average employer-paid premium for all workers in a wage centile. The estimates reflect both insured and uninsured workers.

Source: Authors' tabulations of 1996-2008 MEPS household survey files and MEPS employer survey. 
Figure 8. Trends in Employer Cost for Health Insurance by Wage Decile, 1996 to 2008

Annual Rate of Change in Employer Health Insurance Premiums Per Employed Worker by Wage Decile, 1996-2008

Percent per year

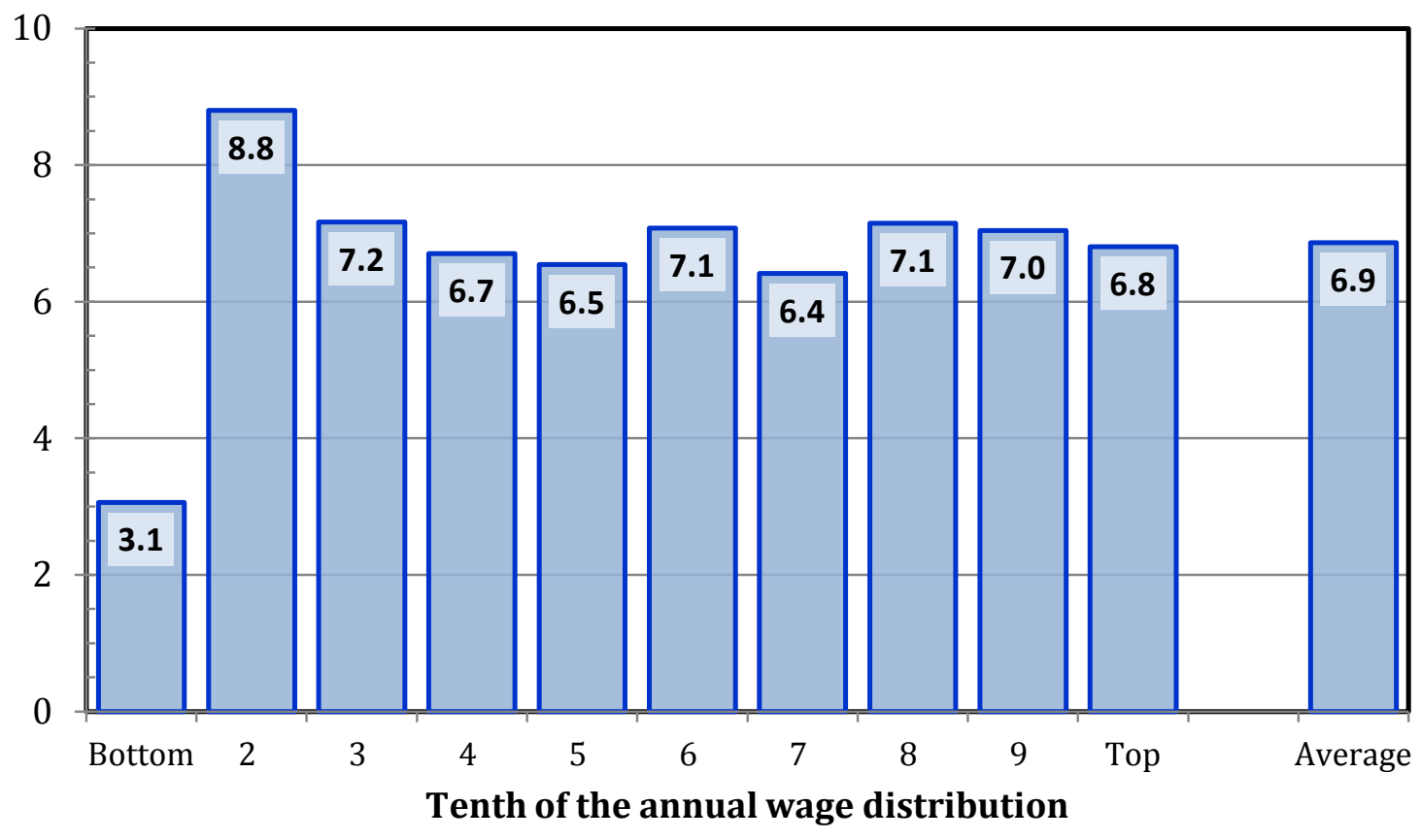

Change in Employer Health Insurance Premium as a Percent of Average Annual Wage, by Wage Decile, 1996 to 2008

Percentage points

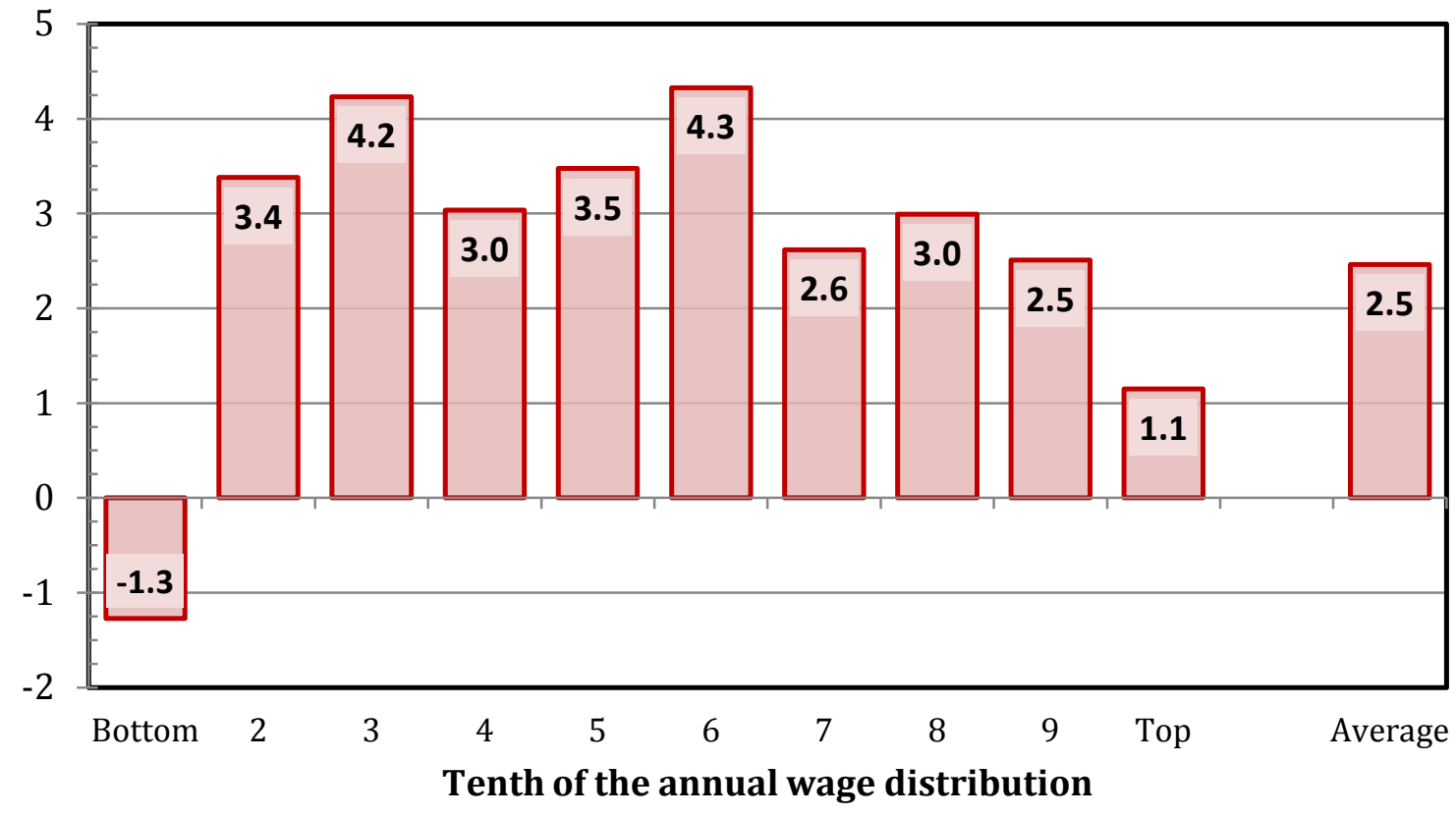


Figure 9. Annual Rate of Change in Real Wage and Employer Health Premiums, by Wage Centile, 1996-97 to 2007-2008

Percent per year

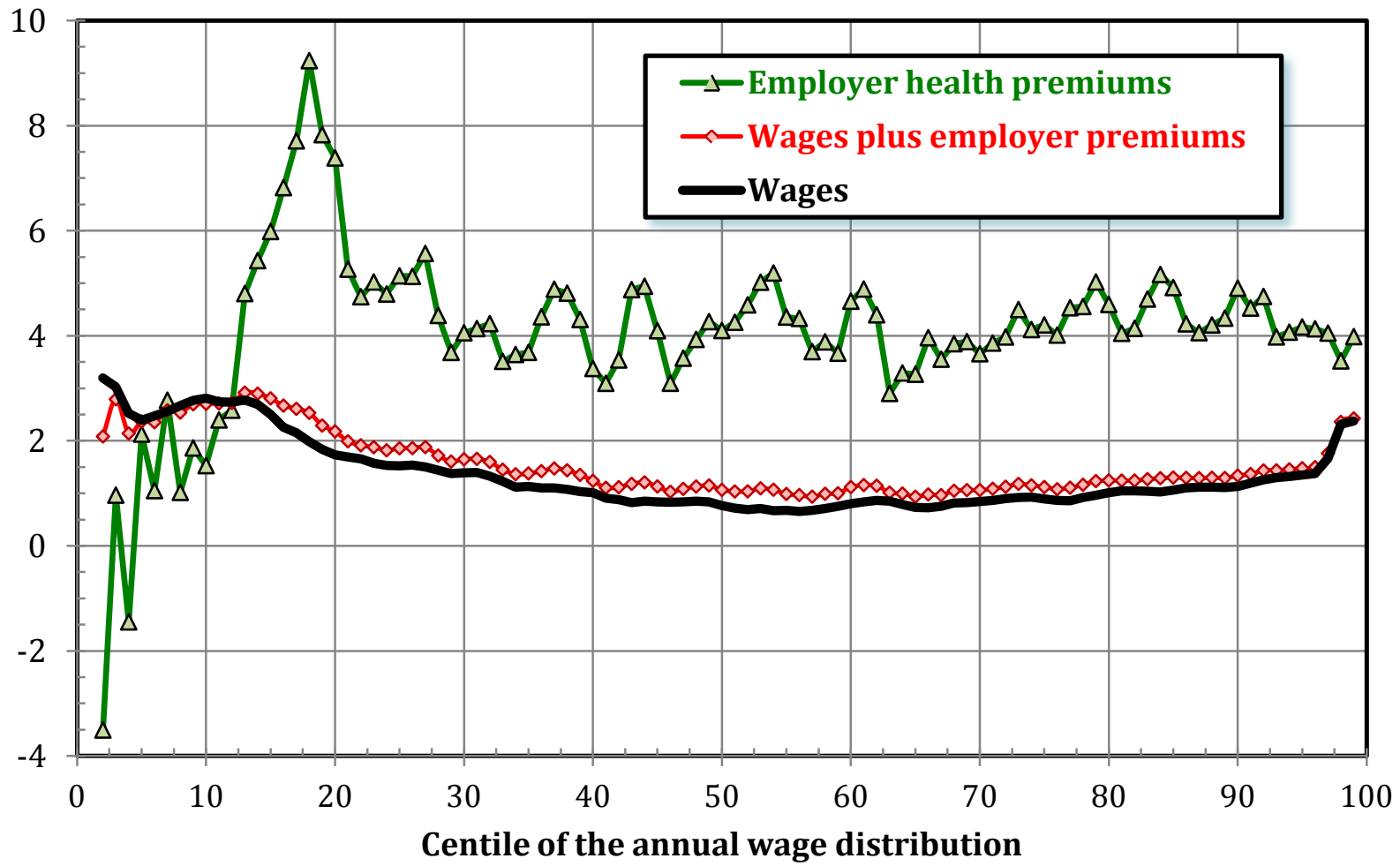

Note: Both wages and employers' premium payments have been deflated using the CPI-U-RS to calculate annual percentage changes.

Source: Authors' tabulations of 1996-2008 MEPS household survey files and MEPS employer survey. 
Figure 10. Estimated Employer Health Insurance Premium as a Percent of Average Annual Wages for U.S. Wage and Salary Workers , 1996-2008

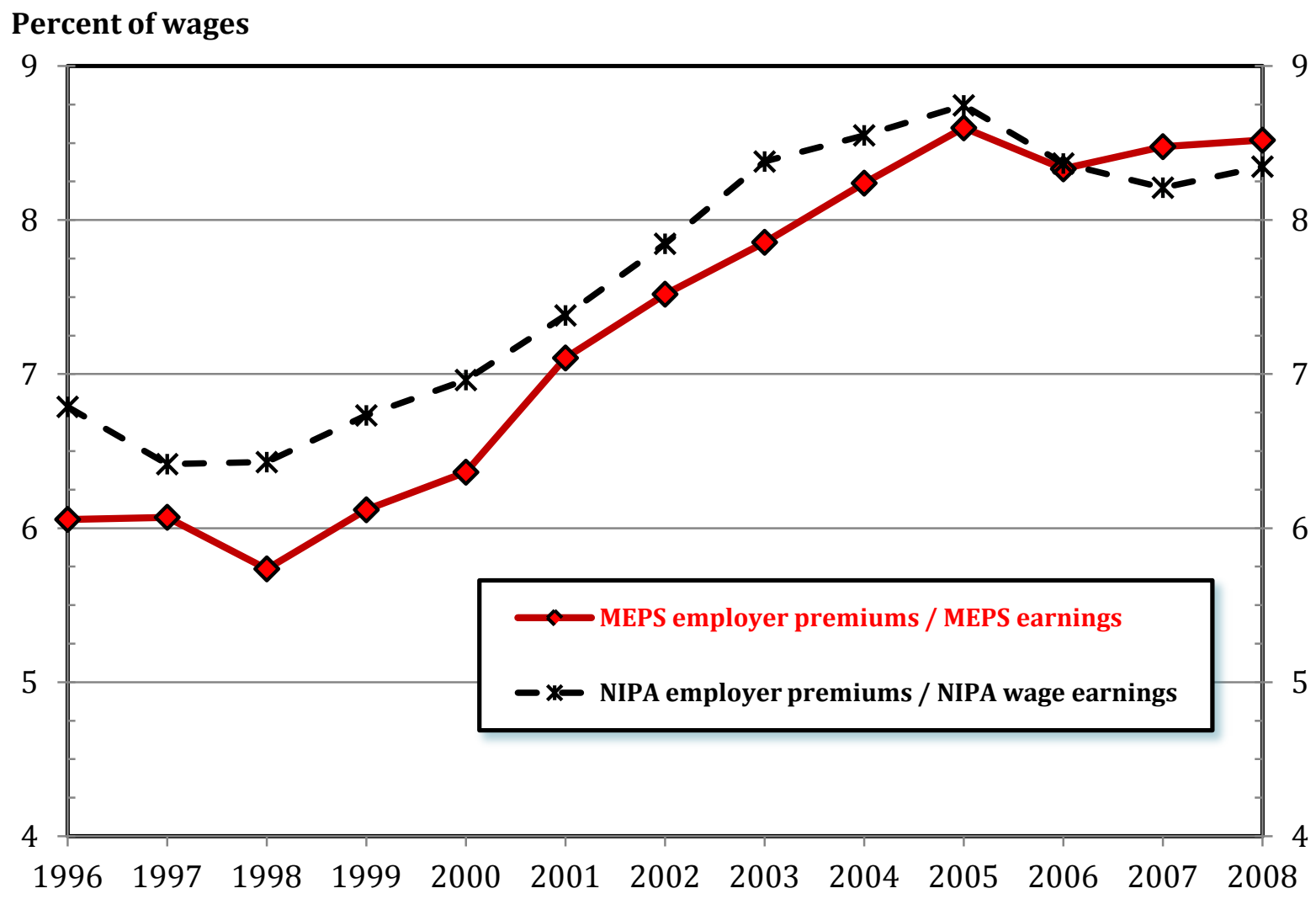

Source: Authors' tabulations of 1996-2008 MEPS household survey files and MEPS employer survey; U.S. Department of Commerce, Bureau of Economic Analysis, National Income and Product Accounts. 
Figure 11. Estimated Employer Health Insurance Premium as a Percent of Average Annual Wage for Wage Earners Above and Below the Maximum Taxed Earnings Amount, 1996-2008

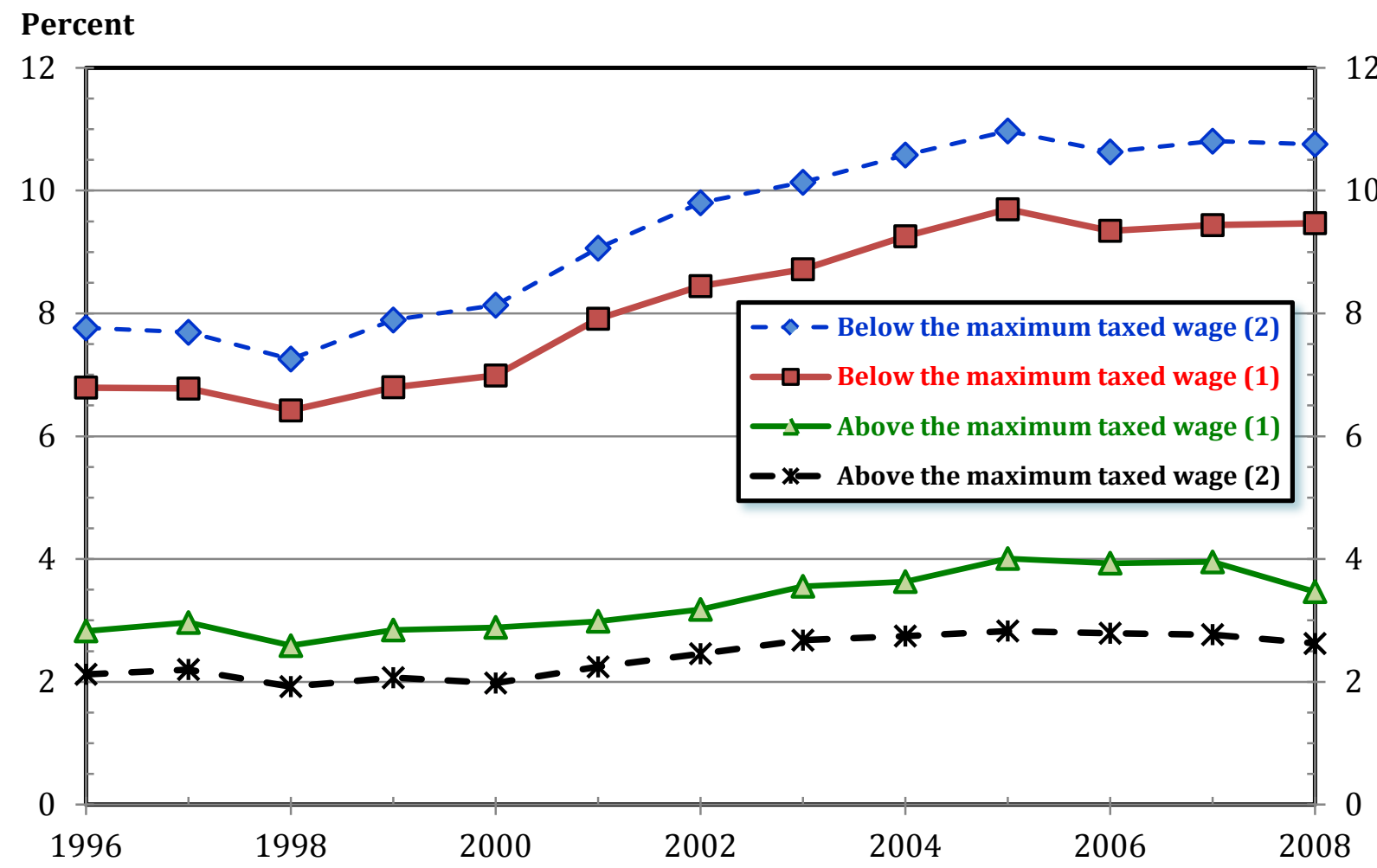

(1) Using unadjusted earnings data from MEPS.

(2) Using estimates of average earnings derived from $\mathrm{W}-2$ records.

Source: Authors' tabulations of 1996-2008 MEPS household survey files and MEPS employer survey; Social Security Administration, various years, Annual Statistical Supplement to the Social Security Bulletin. 
Figure 12. Adjusted Employer Health Insurance Premium as a Percent of Average Annual Wage for Wage Earners Above and Below the Maximum Taxed Earnings Amount, 1996-2008

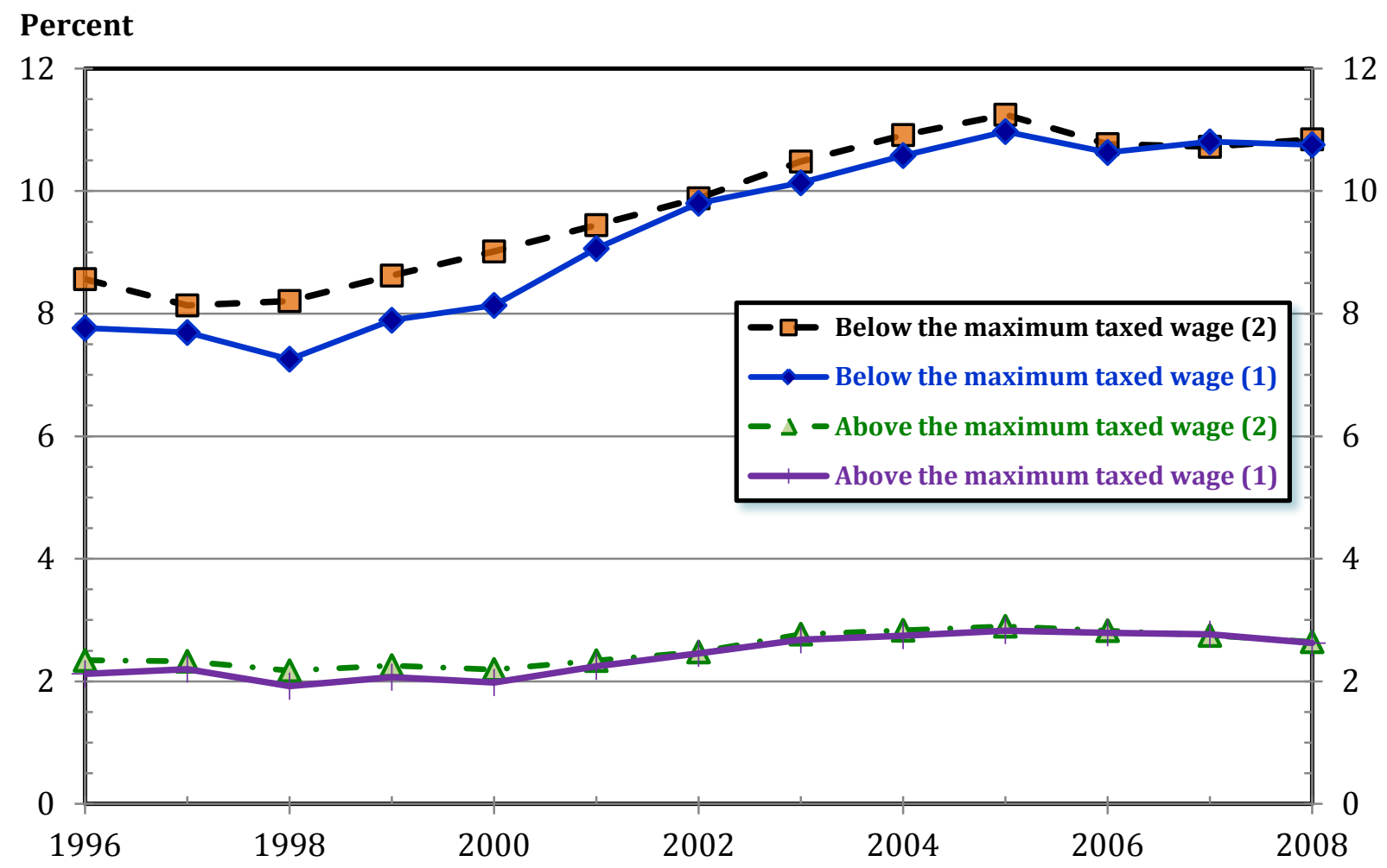

(1) Using unadjusted health insurance premium data from MEPS.

(2) Using adjusted health premium data from MEPS alignged to match the NIPA trend data.

Source: Authors' tabulations of 1996-2008 MEPS household survey files and MEPS employer survey; Social Security Administration, various years, Annual Statistical Supplement to the Social Security Bulletin; U.S. Department of Commerce, Bureau of Economic Analysis, National Income and Product Accounts. 
Figure 13. Post-Reform Source of Insurance for Workers in Employer-Sponsored Health Plans before Reform, by Wage Decile, 2016

\section{Percent}

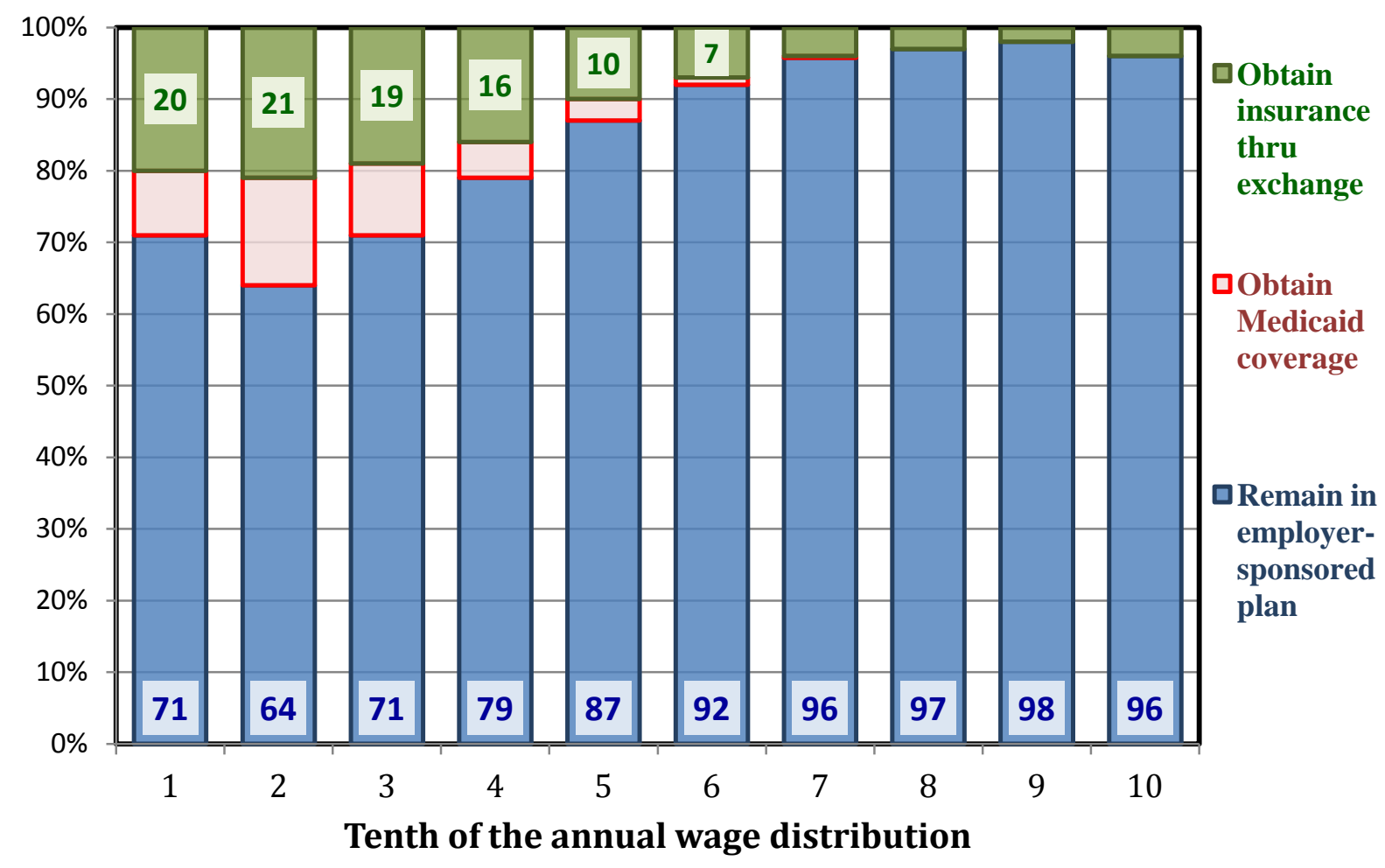

Source: Authors' tabulations based on 2006 and 2008 MEPS household survey files and MEPS employer surveys as explained in text. 


\section{RECENT WORKING PAPERS FROM THE \\ CENTER FOR RETIREMENT RESEARCH AT BOSTON COLLEGE}

Should Households Base Asset Decumulation Strategies on Required Minimum Distribution Tables?

Wei Sun and Anthony Webb, April 2012

Geographic Mobility Among Residents in Seniors Housing and Care Communities:

Evidence from the Residents Financial Survey

Norma B. Coe and April Yanyuan Wu, April 2012

Costs and Concerns among Residents in Seniors Housing and Care Communities: Evidence from the Residents Financial Survey

Norma B. Coe and April Yanyuan Wu, April 2012

Financial Well-Being of Residents in Seniors Housing and Care Communities: Evidence from the Residents Financial Survey

Norma B. Coe and April Yanyuan Wu, April 2012

Residents in Senior Housing and Care Communities: Overview of the Residents Financial Survey

Norma B. Coe and April Yanyuan Wu, April 2012

Social Security Claiming: Trends and Business Cycle Effects

Owen Haaga and Richard W. Johnson, February 2012

Economic Consequences of the Great Recession: Evidence from the Panel Study of Income Dynamics

Barry Bosworth, February 2012

The Changing Causes and Consequences of Not Working Before Age 62

Barbara A. Butrica and Nadia Karamcheva, February 2012

The Impact of Temporary Assistance Programs on Disability Rolls and Re-Employment Stephan Lindner and Austin Nichols, January 2012

Understanding the Growth in Federal Disability Programs: Who Are the Marginal Beneficiaries, and How Much Do They Cost?

Adele Kirk, January 2012

What Explains State Variation in SSDI Application Rates?

Norma B. Coe, Kelly Haverstick, Alicia H. Munnell, Anthony Webb, December 2011

All working papers are available on the Center for Retirement Research website (http://crr.bc.edu) and can be requested by e-mail (crr@bc.edu) or phone (617-552-1762). 